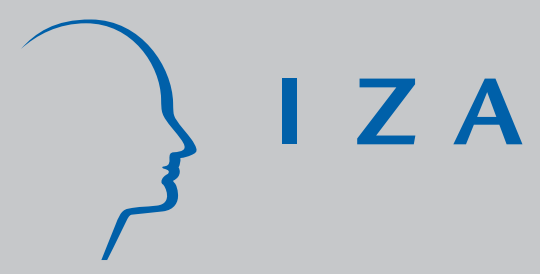

IZA DP No. 2991

What Explains Trends in Labor Force Participation of Older Men in the United States?

David Blau

Ryan Goodstein

August 2007 


\title{
What Explains Trends in Labor Force Participation of Older Men in the United States?
}

\author{
David M. Blau \\ Ohio State University \\ and IZA \\ Ryan Goodstein \\ University of North Carolina at Chapel Hill
}

Discussion Paper No. 2991

August 2007

IZA

P.O. Box 7240

53072 Bonn

Germany

Phone: +49-228-3894-0

Fax: +49-228-3894-180

E-mail: iza@iza.org

\begin{abstract}
Any opinions expressed here are those of the author(s) and not those of the institute. Research disseminated by IZA may include views on policy, but the institute itself takes no institutional policy positions.

The Institute for the Study of Labor (IZA) in Bonn is a local and virtual international research center and a place of communication between science, politics and business. IZA is an independent nonprofit company supported by Deutsche Post World Net. The center is associated with the University of Bonn and offers a stimulating research environment through its research networks, research support, and visitors and doctoral programs. IZA engages in (i) original and internationally competitive research in all fields of labor economics, (ii) development of policy concepts, and (iii) dissemination of research results and concepts to the interested public.
\end{abstract}

IZA Discussion Papers often represent preliminary work and are circulated to encourage discussion. Citation of such a paper should account for its provisional character. A revised version may be available directly from the author. 


\section{ABSTRACT \\ What Explains Trends in Labor Force Participation of Older Men in the United States?*}

After nearly a full century of decline, the Labor Force Participation Rate (LFPR) of older men in the United States leveled off in the 1980s, and began to increase in the late 1990s. We use a time series of cross sections from 1962 to 2005 to model the LFPR of men aged 55-69, with the aim of explaining these trends. We investigate the effects of changes in Social Security rules, lifetime earnings, pension coverage, wages, health, health insurance, and the educational composition of the labor force. Our results indicate that the decline in the LFPR from the 1960s through the 1980s cannot be explained by any of these factors. The recent increase in the LFPR of older men can be explained by changes in the composition of the older male population away from high school dropouts and toward college attendees and graduates. Changes in Social Security may have contributed to the recent increase as well, but the results for Social Security are sensitive to specification.

JEL Classification: J26, J21

Keywords: $\quad$ labor force participation, retirement, social security, pensions

Corresponding author:

David M. Blau

Department of Economics

The Ohio State University

Arps Hall, 1945 N. High St.

Columbus, OH 43210-1172

USA

E-mail: Blau.12@osu.edu

\footnotetext{
*We are grateful for helpful comments from Mark Duggan, Giovanni Mastrobuoni, Jonathan Pingle, Tim Smeeding, and from participants at the 2006 IZA/SOLE Transatlantic Meeting of Labor Economists, the 2007 Annual Meeting of the Population Association of America, and the 2007 research workshop of the Michigan Retirement Research Center. Financial support from the National Institute on Aging (Grant P30 AG024376) is gratefully acknowledged. None of the above are in any way responsible for the content.
} 


\section{Introduction}

The Labor Force Participation Rate (LFPR) of older men in the United States declined for much of the twentieth century. The magnitude and duration of this trend is remarkable. The LFPR of men aged 65 and older fell from 68\% in 1900 to 19\% in 1980 (Moen, 1987). However, this long downward trend ended in the 1980s. More recently, the LFPR of men in some age groups began to rise. For example, after falling to a $20^{\text {th }}$ century low of 24\% in 1985, the LFPR of men aged 65 to 69 increased to over 33\% in 2005. The participation rate for men aged 60 to 64 increased from 55\% in 1985 to 58\% in 2005 (see Figure 1). The U.S. population will be aging rapidly in the next two decades and beyond, with potentially drastic fiscal consequences for Social Security and Medicare. Increasing employment at older ages is a possible solution to the adverse fiscal implications of imminent population aging, so it is important to understand why the downward trend in the LFPR of older men ended, and whether the recent increases are likely to persist.

The goal of this paper is to quantitatively assess alternative explanations for these trends. The main explanations considered include changes in (1) the rules governing Social Security retirement and disability benefits; (2) coverage and type of employerprovided pensions; (3) availability of employer provided retiree health insurance (EPRHI); (4) lifetime earnings, and (5) wage rates available to older men and their wives. We also examine the role of changes in the demographic composition of the older male population, particularly the dramatic increase in educational attainment. We combine data from the Current Population Survey (CPS), the Survey of Income and Program Participation (SIPP), and the Social Security Administration (SSA) to generate a synthetic panel data set spanning the period 1962 to 2005. Individual-level data from the CPS and SIPP are aggregated into cells defined by defined by calendar year, age, and education, and merged, along with aggregate data from the SSA. The data set is used to investigate all of the candidate explanations in a unified framework.

Some of the proposed explanations that we analyze are not new; for example, a number of studies have analyzed the impact of changes in Social Security retirement and disability benefits on the older male LFPR in the 1960s and 1970s (Anderson, Gustman, and Steinmeier, 1999, Hurd and Boskin, 1984; Parsons, 1980; Moffitt, 1987; Bound, 
1989; Krueger and Pischke, 1992; Stewart, 1995). More recently, Pingle (2006) analyzed the impact of the increase in the Social Security Delayed Retirement Credit on employment of older men from the 1980s through 2003, Mastrobuoni (2006) studied the effect of the recent increase in the Social Security Normal Retirement Age, and Gustman and Steinmeier (2006) analyzed the combined effects of these two changes. The connection between trends in pensions and employment trends of older men has also been analyzed (e.g., Anderson, Gustman and Steinmeier, 1999; Friedberg and Webb, 2005), as has the impact of health insurance (Madrian, 1994; Blau and Gilleskie, 2001). An important contribution of our study is to assess alternative explanations in a unified framework and over a long period of time during which there was a major reversal of the long run downward trend in the LFPR of older men. This setting provides a challenge to any mono-causal explanation: such an explanation will have to account for many years of decline, and the recent increase.

We exploit three sources of variation to identify the effects of the main proposed explanatory variables of interest. First, there were several major changes in the rules governing Social Security benefits during the period of our analysis. Many of these changes were birth-cohort-specific, and variation across birth cohorts in Social Security rules is one main source of identification. For example, the 1983 Social Security reforms mandated an increase in the normal retirement age from 65 to 67 phased in over time in several steps, with each step applying to a different birth cohort. Second, we exploit variation across education groups and birth cohort in lifetime earnings, pension coverage and type, and health insurance coverage. It is well known that wage inequality has increased substantially in the U.S. in recent decades, and one of the main dimensions of this increase is across education groups. Social Security rules do not vary by education, but the main determinant of benefits for a given set of rules is average lifetime earnings, which diverges sharply by education group during the period analyzed here. Pension and health insurance coverage trends by birth cohort also vary by education. ${ }^{1}$ Finally, we exploit variation across education groups and birth cohorts in period-specific wage offers.

\footnotetext{
${ }^{1}$ Pension and health insurance coverage can change over time for a given birth cohort, but we do not exploit such variation. Some Social Security rule changes were implemented abruptly and applied to all birth cohorts who had not yet reached the earliest age of eligibility for Social Security at the time of the
} 
Conditional on lifetime average wages, variation across birth cohorts and education groups in the shape of the life cycle profile of wages identifies the work incentive effects of contemporaneous wage offers.

We specify an econometric model that can be interpreted as a linear approximation to the labor force participation decision rule implied by an economic model. We include calendar-year fixed effects in the model to control for secular trends and cyclical patterns in employment that might give rise to spurious correlation between trends in the explanatory factors and trends in LFP. We include education group fixed effects in order to account for permanent unobserved differences across education groups in the relative attractiveness of employment at older ages. And we use age fixed effects to account for features of Social Security and Medicare rules that provide strong agespecific employment incentives and that have remained mostly unchanged during the period covered by our data. Despite all of these controls, unobserved differences across birth cohorts could give rise to spurious correlation between Social Security rule changes and employment trends. Many of our explanatory variables vary by the interaction between birth cohort and education. This makes it possible to control for birth cohort fixed effects that account for the influence of any unobserved birth-cohort-specific factors. However, in practice identification is rather tenuous with a full set of singleyear-of-birth fixed effects, so we present results for several alternative specifications of birth year effects.

We assume that all two-way and higher-order interactions among calendar year, education, birth year, and age can be excluded from the model, and this assumption provides identification. This is a somewhat novel approach to identification in the literature on changes in Social Security employment incentives. Moffitt (1987) uses aggregate time series data, and controls only for age group fixed effects. Krueger and Pischke (1992) use synthetic panel data like ours, but do not disaggregate by education group. They control for age and period effects, but not for birth cohort effects. They argue that "The estimation rests on the assumption that the cohorts under study are otherwise identical except for the benefit notch [caused by the 1977 Social Security

change. These changes provide a source of variation across birth cohorts as well, because of variation in the age at which each birth cohort experienced the change. 
Amendments]. This seems a plausible assumption given that there are likely to be only trivial differences in the average health, private wealth, and occupational mix among cohorts that are so close in birth year.” (p. 427). Their data set includes individuals from 13 different birth years, while ours includes 58 birth year cohorts, so it is obviously important to allow for the possibility of unobserved differences by cohort. Pingle (2006) controls for age and period fixed effects and alternative specifications of birth year effects in his analysis of the effect of changes in the Social Security Delayed Retirement Credit (DRC). Our approach to identification is most similar to that of Pingle, but we exploit the additional variation provided by diverging trends in many of the key variables across education groups.

A priori, changing Social Security rules is the most plausible explanation for the pattern of declining LFP followed by leveling and then increase. Social Security benefits became increasingly generous from 1962 (the first year in our data set) through the mid 1970s. Subsequent reforms in the late 1970s and early 1980s reduced retirement benefits. However, our results indicate that these changes in Social Security can account for only a small proportion of the observed decline in LFP and cannot explain any of the subsequent increase. The results for Social Security are somewhat sensitive to the specification of birth year effects. But even the specification without any birth year controls, which yields the biggest effects of Social Security, implies that changes in Social Security can explain only one fifth of the observed decline in LFP and none of the subsequent increase. The specification with the richest controls for birth year in which Social Security effects are well determined (two-year birth cohort fixed effects) implies that Social Security changes can explain only $4 \%$ of the observed decline. Another $5-7 \%$ of the decline is accounted for by the increased attractiveness of Social Security Disability Insurance. This finding is quite robust. Changes in pensions, health insurance, lifetime earnings, and wages contribute very little to explaining either the LFP decline or the later increase.

Thus, our proposed substantive explanations fail to account for the bulk of the decline in LFP from the 1960s through the 1980s. By providing evidence against the most plausible explanations for the downward trend, our results imply that unobserved changes in preferences, constraints, and institutions are the driving forces, and this is 
confirmed by the importance of the birth year and calendar year fixed effects estimates. This of course leaves open the question of what those unobserved changes were.

Our results do provide a more specific explanation for the recent increase in labor force participation: changes in the education composition of the older male population. Low-participating high school dropouts have been rapidly replaced in recent years by higher-participating college attendees, and college graduates. This trend can explain the entire increase in LFP of older men in recent years, and the results are quite robust on this score. However, this compositional effect is not a fundamental explanatory factor, and it will eventually end as the transition to a more educated labor force is completed. As noted above, Pingle (2006) finds that increases in the Social Security Delayed Retirement Credit (DRC) have played an important role in the recent increase in LFP of older men, and Mastrobuoni (2006) finds that the increased normal retirement age (NRA) for Social Security benefits has also been an important cause of the rise in LFP. We use our estimates to analyze the effects of the recent increases in the DRC and NRA. Our findings indicate that the effects of the DRC and NRA increases are sensitive to specification; some of our estimates suggest that these effects may have been important while others do not. Pingle and Mastrobuoni estimate the "treatment effects" of these changes, while our approach forces the effects of Social Security rules to operate through their impact on the Social Security benefit. Mastrobuoni suggests that changes in the NRA may affect behavior through non-economic channels, by altering social norms or implicit advice from the government on when to retire. Our approach does not pick up effects of Social Security that operate through such mechanisms.

Section 2 provides information on the context of our study, and discusses the contributions of previous studies. Section 3 discusses the conceptual framework for the analysis and the empirical specification implied by the framework. Section 4 describes the data, section 5 discusses the results, and section 6 concludes.

\section{Background}

The long-run trend of declining labor force participation among older men is not unique to the United States. Similar patterns are found in other industrialized countries, suggesting that the principal explanations for the trend toward earlier retirement may be 
common across developed nations. Analysts generally attribute the long-run downward trend to rising lifetime income as a result of growing real wages (Costa, 1998; Burtless and Quinn, 2000). Other things equal, wealthier men have a higher lifetime demand for leisure, and can more readily "afford” to retire early. However, the increase in the LFPR of older men since the late 1990s has occurred during a period when real earnings have continued to increase in the U.S., at least for some groups. This suggests that the wealth effect may have diminished in importance or that other forces now dominate the wealth effect. Costa (1998) cites a number of studies which suggest that the effect of retirement income on retirement behavior has diminished in recent years, in part because retirement has become more attractive due to changing social norms and the development of leisure technologies that have made retirement more affordable and enjoyable. Kopecky (2005) calibrates a model that explains the trend in the older male LFPR since 1850 as resulting from increasing real wages and declining prices of goods that are complementary with leisure. Her model captures the long run decline in the LFPR, but fails to predict the leveling and reversal of the trend since the mid 1980s, and does not capture differences in the rate of decline by age group.

Circumstantial evidence suggests that changes in the generosity and structure of Social Security may have affected labor force behavior of older men. Benefits were increased often from the inception of Social Security in 1935 through the early 1970s, coinciding with declining older male LFP. The end of the downward trend in the LFPR of older men in the 1980s coincides with several changes to Social Security policy that increased the incentive to work at older ages. Amendments in 1977 reduced benefits for men who turned 65 beginning in 1982. The 1983 amendments increased the normal retirement age in two month increments per year from 65 in 1999 to 66 in 2005, effectively reducing lifetime benefits ${ }^{2}$. As noted above, the 1983 amendments also stipulated increases in the Delayed Retirement Credit (DRC), which is an increase in the benefit for delaying entitlement past the normal retirement age. Finally, amendments in 1983 (effective in 1990) and in 2000 modified the Social Security Earnings Test (SSET),

\footnotetext{
${ }^{2}$ A person who retires at the normal retirement age of 66 in 2005 collects benefits for a full year less than an equivalent individual who retired at the normal retirement age of 65 in 1999, holding constant life expectancy. The reduction in lifetime benefits is also reflected in an increased penalty associated with
} 
first reducing and then eliminating the implicit tax on earnings for men at and above the normal retirement age. However, the LFPR of older men was declining for many years before the inception of Social Security (Costa, 1998).

There is not a consensus on the effects of changes to Social Security on the LFPR of older men. Moffitt (1987) uses time-series data to assess the impact of increases in benefits from the 1950s through the 1970s. He concludes that unanticipated Social Security policy changes can explain no more than $20 \%$ of the observed decline in the 1970s. However, in a similar analysis using a longer time-series, Stewart (1995) finds that up to $40 \%$ of the change in the LFPR of older men between 1965 and 1990 can be attributed to changes in Social Security benefits. Researchers have also used individuallevel panel data to assess the impact of particular SS amendments. Hurd and Boskin (1984) find that increases in Social Security benefits between 1970 and 1972 account for nearly the entire decline in the LFPR of older men between 1969 and 1973. Blau (1994) finds that changes in Social Security benefits can explain part of the decline in older male LFP in the 1970s, but the majority of the decline is unexplained. Kreuger and Pischke (1992) use synthetic panel data and find that the 1977 amendments had almost no impact on LFP rates of older men in the 1970s and 1980s. There is also disagreement over the role of Social Security Disability Insurance (SSDI) in explaining the decline in LFP at ages before eligibility for retirement benefits (Parsons, 1980; Bound, 1989).

Changes in the availability and structure of private pension plans may have affected LFP at older ages. Traditionally, firms have offered their employees Defined Benefit (DB) pension plans, in which benefits are a function of age and job tenure at the date of retirement, and earnings in the years prior to retirement. DB plans are typically structured so as to give workers a strong incentive to retire at the earliest age of benefit eligibility, as the benefit increase for later retirement is small (Lazear, 1986). However, in recent years employers have increasingly offered Defined Contribution (DC) plans in place of DB plans. Participation in DB plans fell from 84\% in 1980 to 33\% in 2003 among full-time employees of medium and large private firms, with a corresponding increase in DC plan participation (Employee Benefit Research Institute, 2005). In DC

claiming benefits before the normal retirement age. A further phased increase in the normal retirement age from 66 to 67 is scheduled to take place from 2017-2022. 
plans pension wealth accumulates as a function of employer and employee contributions and the returns on those contributions. DC plans do not cause disincentives for working at older ages, because the pension value depends only on the account balance rather than age or job tenure. As participation in DB plans has declined, disincentives for working at older ages associated with DB pension plans have become less important. Friedberg and Webb (2005) find that workers covered by DC pensions retire two years later than otherwise similar workers covered by DB pensions. However, these pension plan changes appear at older ages only with a significant lag, since the changes usually affect only new employees.

Increased LFP among married women could be related to the reversal in LFP trends of older men since the mid 1980s. The LFPR of married women has nearly tripled since 1950 (Costa, 2000). Hurd (1990), Blau (1998), Gustman and Steinmeier (2000), and others find that working husbands and wives tend to retire at the same time. Thus a husband may delay retirement until his wife, who is typically younger, becomes eligible for Social Security or pension benefits. In addition, husbands may simply value leisure more highly when it is shared with a spouse. Coile (2004) finds evidence that a husband is more likely to delay retirement if his wife will be entitled to larger retirement benefits from Social Security and pensions, and that men strongly prefer leisure shared with the spouse to being retired while the spouse continues to work. The connection between increasing LFP of older married women and the recent increase for older men was analyzed by Schirle (2007), who found that about one quarter of the increase in older male LFP in the U.S. could be accounted for by growth in participation by older wives.

Changes in the availability of employer provided retiree health insurance (EPRHI) may have caused changes in LFP of older men. Eligibility for public health insurance for the elderly (Medicare) begins at age 65 in the U.S. Men under the age of 65 without EPRHI who choose to retire must bear the cost of purchasing health insurance coverage from another source or go uninsured, bearing the full brunt of medical expenditure risk. Blau and Gilleskie (2001) estimate that $13 \%$ of the decline in the LFP rate of men aged 55 to 59 between 1965 and 1984 can be attributed to increases in the availability of EPRHI. If the availability of EPRHI has declined in recent years then LFP rates of older men may be increasing as a result (Madrian, 1994). 
Trends in the health of older men have been discounted as a potential explanation for the long run decline in the LFP rate of older men. Health has a major impact on labor force behavior, but trends in health have been positive rather than negative in recent decades (Burtless and Quinn, 2000). Similarly, changes in the occupational composition of the labor force are unlikely to have caused much of the changes in LFP rates of older men. Costa (1998) finds that the decline of the farming sector did not contribute to declines in LFP rates in the early $20^{\text {th }}$ century. However, Quinn (1999) speculates that shifts in the U.S. economy from manufacturing to service may be contributing to recent increases in LFP rates of older men, as the physical demands of working may have declined.

\section{Conceptual Framework and Empirical Model}

Here, we briefly outline our conceptual approach, and then derive an empirical specification that can be interpreted as an approximation to the decision rule for employment at older ages implied by the conceptual approach. Each period a man, and his wife if he is married, chooses consumption and labor force participation to maximize the expected present discounted value of remaining lifetime utility, subject to a set of constraints ${ }^{3}$. Utility is derived from leisure and consumption, and preferences may depend on individual characteristics such as age, health, race, marital status, and education. The constraints are:

1. Social Security rules that determine (a) the retirement benefit as a function of lifetime earnings, birth year, and age of entitlement; and (b) the Disability Insurance (SSDI) benefit as a function of lifetime earnings, birth year, and health.

2. A set of pension and health insurance constraints. These include: (a) Whether an individual is covered by a Defined Benefit (DB) pension plan, and if so, the rules that determine benefits as a function of age, job tenure at the pension-providing firm, and

\footnotetext{
${ }^{3}$ We focus on behavior at older ages, rather than attempting to model the full life cycle, as in French (2005) and Moffitt (1987). Hours of work of men are clustered around full-time hours (approximately 2000 per year) and to a lesser extent part-time or part-year hours (approximately 1000 per year) (Rust, 1990). At younger ages there is very little non-participation by men. Withdrawal from the labor force at older ages typically involves an abrupt transition from full time or part time to zero hours of work, and understanding this behavior is unlikely to be aided by analysis of hours of work choices at younger ages. Moffitt's (1987) evidence suggests that younger men do not take account of Social Security and pension incentives that will affect their standard of living far in the future when they are retired.
} 
cumulative earnings at the firm. (b) Whether an individual is covered by a Defined Contribution (DC) pension plan, and if so, the rules that determine eligibility and benefits as a function of the amount in the DC pension account and age. (c) Whether a man is covered by employer-provided health insurance with retiree benefits, and if so, the plan rules that determine reimbursement of the individual's medical expenditure. We take pension coverage and type and health insurance coverage and type as given.

3. The net worth of the household at the beginning of the period, and the wage offer to the man and his wife, if he is married, for employment in period t. Wage offers are taken as given by individuals.

4. The individual's subjective probability distribution over random variables, including individual attributes such as future health and wages, and aggregate variables such as future Social Security rules and asset returns.

The labor force participation choice in period $t$ is made by comparing $\mathrm{V}_{1 \mathrm{t}}\left(S_{t}\right)$ and $\mathrm{V}_{0 \mathrm{t}}\left(S_{t}\right)$, where $S_{t}$ is the vector of state variables that characterizes the man's situation in period $\mathrm{t}$, and $\mathrm{V}_{1 \mathrm{t}}\left(S_{t}\right)$ and $\mathrm{V}_{\mathrm{ot}}\left(S_{t}\right)$ are the value functions associated with participation and non-participation, respectively, conditional on the optimal level of consumption in each case and the optimal level of hours of work in the case of participation. The state variables are described above (Social Security rules, pension coverage and rules, net worth, wage rates, health, etc.). The employment decision rule is to participate in the labor force in period $t, \mathrm{~L}_{t}=1$, if $\mathrm{V}_{1 \mathrm{t}}\left(S_{t}\right)>\mathrm{V}_{0 \mathrm{t}}\left(S_{t}\right)$, and otherwise to not participate, $\mathrm{L}_{\mathrm{t}}=0$.

Now consider how to derive a useful empirical approximation to the decision rule for $\mathrm{L}_{\mathrm{t}}$. We discuss Social Security, pensions and health insurance, wage rates, and assets, in turn.

1. Social Security. The parameters of the Social Security system, together with an individual's average lifetime earnings and beliefs about future benefit rules, wages, health, and mortality fully characterize Social Security benefits in the model. However, a specification that includes the rules themselves is neither informative nor parsimonious. There are dozens of parameters in the Social Security rules, and it would be difficult to interpret the effects of individual parameters. Instead, we approximate the effects of Social Security rules with a small number of variables measuring the benefit that an individual would receive as a result of following a specified sequence of labor supply 
choices and exiting the labor force at a specified age, conditional on experiencing a specified earnings sequence. There are an infinite number of such Social Security benefit variables, depending on the labor supply and wage sequences specified, but they are all highly inter-correlated since they depend on the same underlying rules. We use the following variables as "approximately sufficient statistics" for the effect of Social Security on $\mathrm{L}_{\mathrm{t}}^{4}$ :

(a) $\mathrm{SSB}_{\text {nra }}$, the retirement benefit an individual would receive at the normal retirement age $(n r a)^{5}$ if he were to work full time in every year from the age of labor force entry through age $n r a-1$ at the mean of his age-specific wage offer distribution, and were to leave employment at age $n r a$ and never work again. SSB $_{\text {nra }}$ varies across individuals only as a result of differences in the rules in effect for different birth cohorts and differences in lifetime earnings. This variable is intended to capture the wealth effect of Social Security (Moffitt, 1987), so we expect it to have a negative effect on LFP. In order to isolate the effects of rule changes from lifetime earnings changes, we include in the model the average lifetime earnings implied by the assumed age-specific earnings sequence.

(b) $\mathrm{SSB}_{62}$, the retirement benefit the individual would receive at age 62 (the earliest age at which the Social Security retirement benefit can be claimed) if he were to work full time from the age of labor force entry through age 61 at the mean of his agespecific wage offer distribution, leave employment at age 62, and never work again. This variable is intended to capture the effect of the early retirement penalty. In order to facilitate this interpretation, it is specified in differenced form as $\mathrm{SSB}_{62}-\mathrm{SSB}_{\text {nra. }}$. A higher

\footnotetext{
${ }^{4}$ Many studies of the effect of Social Security on retirement convert the monthly benefit into a stock of "Social Security wealth" using an assumed interest rate and mortality schedule. This approach is based on the assumption of a perfect capital market. This is not a very appealing assumption in the context of Social Security, given that a liquidity constraint is the only plausible reason for the large spike in labor force exit at the earliest entitlement age. Using the benefit instead of a wealth measure means that the coefficient estimate captures the effects of liquidity constraints, discounting, and mortality expectations, as well as retirement incentive effects. This should be kept in mind when interpreting the estimates. We discuss below alternative specifications using Social Security wealth. Other studies use the replacement rate (the benefit divided by earnings) as an explanatory variable to capture the effect of Social Security. We include the wage offer, thus implicitly accounting for the replacement rate.

${ }^{5}$ The normal retirement age is 65 for individuals born in or before 1937; $65+x / 6$ for birth years $1937+x$, $x=1, \ldots, 5$; 66 for birth years 1943-1954; $66+x / 6$ for birth years $1954+x, x=1, \ldots, 5$; and 67 for birth years $1960+$.
} 
value of the variable implies a smaller early retirement penalty, so it should have a negative effect on labor force participation.

(c) $\mathrm{SSB}_{70}$, the retirement benefit the individual would receive at age 70 if he were to work full time through age 69 at the mean of his age-specific wage offer distribution, leave employment at age 70, and never work again. Since the 1983 Social Security amendments, there has been no increase in the benefit for delaying retirement past age 70. This variable picks up the effect of the Delayed Retirement Credit (DRC), which rewards later claiming with higher benefits. It is specified in differenced form as $\mathrm{SSB}_{70^{-}}$ $\mathrm{SSB}_{\text {nra. }}$ A higher value implies a larger incentive to delay retirement, so it should have a positive effect on the LFPR. ${ }^{6}$

(d) $\mathrm{SSB}_{\mathrm{td}}$, the Social Security disability benefit the individual would receive in period $t$ if he were to work full time through age $t-2$ at the mean of his age-specific wage offer distribution, withdraw from the labor force at age $t-1$, and become eligible for SSDI at age t. The requirement of not working at age t-1 is intended to capture the waiting period, which in reality is five months. $\mathrm{SSB}_{\mathrm{td}}$ is zero from the $n \mathrm{ra}$ onward, because the SSDI benefit is converted to an OASI benefit at the nra. This variable is intended to capture the incentive effects of SSDI benefits, and is expected to have a negative effect on LFP. ${ }^{7}$

This specification captures the main labor force participation incentives of Social Security: the wealth effect, the early retirement penalty, the delayed retirement credit, and the SSDI incentive effect. It does not account for several other channels through which Social Security might affect retirement decisions. The most important omitted channels are the Social Security Earnings Test (SSET), spouse benefits, and the payroll tax. The SSET imposes a tax on benefits for each dollar of earnings above a specified threshold, but repays the benefits lost due to the earnings test when the individual's earnings

\footnotetext{
${ }^{6}$ It is worth noting that a standard life cycle model implies that benefits available conditional on retirement at alternative ages should affect LFP at a given age. Thus, for example, the benefit available conditional on exit from the labor force at age 70 will affect the retirement decision at age 55 . The model does not condition on past labor force participation, nor does it assume that exit from the labor force is irreversible. ${ }^{7}$ A higher SSDI benefit increases the incentive to apply for SSDI and withdraw from the labor force, conditional on health. Many SSDI applications are denied, so the coefficient on $\mathrm{SSB}_{\mathrm{td}}$ picks up both the incentive effect and the cost of applying for SSDI given that the application may be unsuccessful. See Autor and Duggan (2003), Chen and van der Klaauw (in press), and Benitez-Silva et al. (2004) for recent analyses of SSDI.
} 
subsequently drop below the threshold. The SSET has been found to have moderate labor supply effects on affected individuals (those who would work in the absence of the SSET), but affected individuals are in practice a small share of the older population (Friedberg, 2000; Burtless and Moffitt, 1985). We ignore it here because there is no straightforward way to measure its effect in our framework.

A married man's wife is eligible for a Social Security benefit based either on her own earnings record or her husband's earnings record, depending on which provides the larger benefit. While it is reasonable to specify Social Security benefits for men based on the assumption of continuous full time employment for many years, this assumption would not be reasonable for married women. In the absence of longitudinal data on the earnings histories of wives, there is no straightforward way to compute a reasonable approximation to the benefit for which a spouse would be eligible, so we omit spouse benefits. $^{8}$

Finally, we do not model the Social Security payroll tax, which is a proportional levy on covered earnings up to a maximum taxable amount. The only variation in the tax rate in a given year is that the marginal rate is zero for men whose earnings are above the taxable maximum. Given our focus on Social Security benefits computed at mean earnings, this source of variation is irrelevant because mean earnings are below the taxable maximum for nearly every cell in our data ${ }^{9}$. Time series variation in the payroll tax is not cohort-specific, and is picked up by calendar year effects. We discuss below the sensitivity of our results to ignoring taxes.

We investigated whether the Social Security variables described above are "approximately sufficient statistics" for the effects of Social Security by computing other Social Security benefit variables, assuming different earnings paths and different ages of entitlement. We regressed each of these other variables on the three retirement benefit variables described above and the associated average lifetime earnings. For benefits available at alternative claiming ages using the same earnings history, the $\mathrm{R}^{2}$ exceeded 0.99 in every case. For benefits based on alternative earnings histories with a similar

\footnotetext{
${ }^{8}$ Labor force participation of married women increased substantially during the period covered by our analysis, so the wives of more recent cohorts of married men are more likely to qualify for a benefit based on their own earnings history rather than the husband's earnings history. Thus it would be quite misleading to assume that all wives receive a spouse benefit rather than a benefit based on their own earnings record.
} 
lifetime average value but a different slope, the $\mathrm{R}^{2}$ was in the range 0.91 to 0.95 . For benefits based on alternative earnings histories with lower or higher lifetime average value, the $\mathrm{R}^{2}$ was in the range 0.80 to 0.95 . These results demonstrate that the Social Security variables included in the specification capture most of the variation in Social Security rules.

2. Pensions and health insurance. We have data on coverage by Defined Benefit and Defined Contribution pension plans, but we do not observe the rules or the state variables that determine benefits (job tenure, average earnings at the pension job, the DC account balance). Similarly, we observe whether an individual is covered by an employer-provided health insurance plan with retiree benefits, but we do not observe the associated rules or state variables. We include the coverage variables, and interpret their effects as "local average treatment effects." That is, the effect of coverage by a given type of pension or health insurance plan may change if the rules or state variables change.

3. Wage rates. We observe the wage rate for an individual only if he or she chooses to work. To circumvent this problem, we use the fitted value from a birth-yearsex-education-specific log wage regression on age, race, marital status, region, and metropolitan status. These regressions are not corrected for selection on unobservables, since there is no plausible source of identification. The Appendix describes the regression specification in more detail. The predicted value of the man's log wage offer, and, if he is married, the spouse's predicted log wage offer, are included in the labor force participation model.

4. Net worth. We lack data on net worth for most of our sample, so it is not feasible to include net worth in the analysis. This is a significant limitation of our specification, although in practice most studies of retirement have found a very small effect of net worth (e.g. Blau, 1994; Diamond and Hausman, 1984). However, if most wealth accumulation results from saving out of earnings, average lifetime earnings may pick up the effect of net worth. We discuss below the robustness of the results to controls for wealth proxies.

In order to facilitate aggregation, we specify a linear model for individual labor force participation. We aggregate the data within cells defined by calendar year, single

\footnotetext{
${ }^{9}$ Mean annual earnings are greater than the maximum taxable earnings for some cohorts from 1960-1972.
} 
year of age, and four categories of educational attainment (high school dropout, high school graduate, some college, and college graduate). The dependent variable is the labor force participation rate, and the explanatory variables are Social Security benefits, lifetime average earnings, pension and EPRHI coverage, wage rates, health status, marital status, and race. As noted above, we also include fixed effects for calendar year, age, education, and alternative controls for birth year.

An important issue for identification and interpretation is how to model expectations about Social Security rule changes. Krueger and Pischke (1992) assume myopic expectations in their analysis of the 1977 reform, arguing that because this reform unexpectedly reduced benefits after a long series of previous benefit increases, it is unlikely that the benefit reduction was foreseen by individuals. This may be a reasonable assumption for the 1977 reform, but the assumption of myopia is less tenable in years prior to 1977. There were eight changes to Social Security rules between 1961 and 1975, each increasing the generosity of benefits. We conduct our analysis under two alternative extreme assumptions: perfect foresight and complete myopia. We cannot defend either assumption as appropriate for the entire period of our analysis, but we can determine how sensitive the results are to these alternative assumptions. ${ }^{10}$

\section{Data}

We estimate the econometric model on a synthetic panel data set constructed from micro data from the Current Population Survey (CPS) and the Survey of Income and Program Participation (SIPP), combined with aggregate data from the Social Security Administration (SSA). Individual records on men aged 55-69 from the CPS and SIPP are aggregated into cells defined by single year of birth, single year of age, and four education groups (high school dropout; high school graduate; some college; college graduate). The aggregated data from the CPS and SIPP are merged at the cell level. The result is a synthetic panel data set covering 58 birth years (1892 to 1949) between 1962 and 2005, although no cohort has data for all of these years, and some cohorts are dropped due to small sample sizes. Data from 1963 are dropped because there is no 
information on education in the 1963 CPS. Because we focus on LFP behavior at older ages, we include only cohorts that can be observed at ages 55 to 69 in our sample. The estimation sample contains observations on 2,453 cells with at least 30 observations per cell. Cells with fewer than 30 observations are dropped. ${ }^{11}$

Most of the data are from the March supplement to the CPS from 1962 to 2005. These data are used to construct measures of demographic characteristics, labor force participation, and wage rates of older men and their spouses. Figure 2 shows the trend in the male LFPR at ages 55-69 averaged over all education groups for the period 19622005. A man is treated as a labor force participant if he worked or was actively searching for work (unemployed) in the week prior to the March survey. The LFPR in this age range declined slowly in the 1960s, and then fell from over $70 \%$ in the early 1970s to $55 \%$ in the mid 1980s. The LFPR was essentially flat from the mid 1980s to the mid 1990s, and then rose by about five percentage points after the mid 1990s. Figure 3 shows the trends for four age groups separately. The downward trend through the mid 1980s was common to all of the age groups, but sharpest at the older ages. And the rebound in LFP since the 1990s occurred only for the older groups (65-66 and 67-69). Trends in the education distribution of the older male population during this period are shown in Figure 4, which illustrates the rapid shift from a large majority of high school dropouts in 1962 to mainly high school graduates and college attendees today. Figure 5 shows that the LFPR is on average about 10 points lower for high school dropouts than for high school graduates. Thus, educational composition effects may be important.

Figure 6 shows the trend in bad health, based on CPS data. We follow Peracchi and Welch (1994) in defining a man to be in bad health if he did not work full time in the survey reference week or in the previous year and he attributes that choice to disability. The CPS measure shows a decline in the incidence of poor health from $18-20 \%$ in the early 1970 s to around $12 \%$ in the 1990s. Because this measure depends on labor force

\footnotetext{
${ }^{10}$ Moffitt (1987) specified a time series forecasting model of benefit changes in his analysis of the 1950s and 1960s. We tried the same approach for our period, but the results yielded implausible forecasts, so we did not pursue this approach.

${ }^{11}$ The CPS reports age at the survey date, but not birth year. The majority of individuals interviewed in March will have their birthday later in the year. For simplicity, we assume that all men have their birthday after the March survey date, implying that birth year = survey year minus age minus one. Below, we discuss the robustness of our results to alternative assumptions about birth year. Birth year is available in the SIPP.
} 
status in previous periods it is likely to be endogenous with respect to LFP choice in the current period. Figure 6 also shows the incidence of poor health for the same cohorts of men based on data from the National Health Interview Survey (NHIS). The NHIS measure is derived from a question on general health status, with responses of fair and poor treated as "bad” and responses of good, very good, and excellent treated as "good." Although the levels of the two measures differ, they follow the same trend over time. The NHIS measure is available only from the 1970s, so we use the CPS measure because it is available for the 1960s as well.

We use data from the Annual Statistical Supplement to the Social Security Bulletin on average taxable earnings by cohort and age to construct measures of benefits. The published SSA data are combined with CPS earnings data to form earnings histories that are input to the ANYPIA benefit calculator provided by SSA to compute benefits. Details on the construction of the benefit measures are provided in the data appendix. Figure 7 illustrates trends in the real SSB for entitlement at ages 62, the $n r a$, and 70 . $\mathrm{SSB}_{\text {nra }}$ follows an upward trend during the entire period, but with much slower growth in the 1980 s than in other periods. The $\mathrm{SSB}_{62}$ trend is parallel to the $\mathrm{SSB}_{\text {nra }}$ trend until the late 1990s, when it begins to diverge. The divergence is due to the increase in the penalty for early retirement resulting from the increase in the $n r a$ from 65 to 66 . SSB 70 rises relative to $\mathrm{SSB}_{\text {nra }}$ for most of the period, but the increase is especially notable in the 1990s and 2000s as the increased DRC legislated in the 1983 reform is phased in.

Figure 8 shows the trend in the SSDI benefit, averaged over ages 55-64. The trend is generally upward, but is more irregular than the retirement benefit trend because benefits are age-specific, and the rules used to compute the potential benefit are the same for all awardees in each year regardless of birth year. The "notch" induced by the 1977 amendment is clearly visible in this case. Figure 9 shows trends in lifetime average monthly earnings by education group, and highlights the rapid growth in lifetime earnings disparity by education.

Figures 10 and 11 show education-specific trends in predicted log real wage rates for men aged 55-69 and for wives of married men in this age range. Real wages of older men and women have been stagnant or declining since the 1970s, and dispersion across education groups has increased. 
We use data from topical modules of various SIPP panels to measure participation in DB and DC pensions, and availability of EPRHI. Respondents are asked if they are covered by EPRHI only if they are receiving income from a private pension at the time of the survey. To deal with small sample sizes for early birth cohorts, our measures of pension participation and availability of EPRHI are averaged across the earliest birth years separately by education group. Data for the earliest birth years likely suffer from mortality bias. There may be additional biases for our measure of EPRHI, as individuals covered by EPRHI are more likely to be retired and receiving retirement income than those not covered by EPRHI. Details on how DB, DC, and EPRHI indicators are constructed are included in the appendix. Figure 12 shows that for men aged 55-69 DB pension coverage trended upward until the 1980s and began to decline in the 1990s. DC pension coverage increased slowly but steadily during the entire period. EPRHI coverage rose through the 1980s and has been roughly constant since then.

\section{Results}

\section{A. Estimates}

Regression results are shown in Table 1 for several specifications of the LFPR model for men aged 55-69, using data from 1962 through 2005. All specifications shown

in Table 1 are based on the assumption of perfect foresight with respect to Social Security rules, and all include fixed effects for single years of age, single calendar years, and education groups. The columns differ by how birth year effects are specified. The first specification has no controls for birth year, the second includes a quadratic birth year trend, the third includes dummies for five-year birth-cohort group effects, the fourth includes dummies for two-year birth-cohort group effects, and the last includes a full set of single-year-of-birth effects. Figure 13 shows the actual and fitted trends in LFP for all of the specifications. All of the specifications provide a good fit to the data, both overall, and by age group. In fact, the alternative birth year specifications are virtually indistinguishable in terms of model fit. The test statistics at the bottom of the columns of Table 1 indicate that the no-birth-year-effects model in column 1 is strongly rejected against the quadratic birth year specification (and against all of the other specifications; results not shown), while the two-year-birth-cohort specification in column 4 is not 
rejected against the specification with a full set of birth year fixed effects in column 5 .

As discussed above, the Social Security benefit for retirement at the normal retirement age $\left(S S B_{n r a}\right)$ should capture the wealth effect of Social Security, so we expect it to have a negative effect on LFP. The results confirm this expectation across all of the specifications except the last. The magnitude of the effect declines across the columns of Table 1, as richer controls for birth year effects are added. The coefficient estimate of 0.21 in column 1 implies an elasticity of LFP with respect to $S S B_{n r a}$ of -0.41 at the means, compared to an elasticity of -0.10 for the estimate in column 4 . The gain in SSB from claiming at 70 rather than at the $n r a$ is predicted to have a positive effect on the LFPR, and the results in the first four columns confirm this. The implied elasticity ranges from .07 in the first column to .02 in column 4 , and the coefficient estimate is significantly different from zero in the first three columns. The gain in SSB from claiming at 62 rather than at the nra is expected to have a negative effect on LFP. The coefficient estimate is negative in columns 1 and 3, but positive in columns 2, 4, and 5. The effects are small and insignificantly different from zero in the first four columns. The coefficient estimate on the SSDI benefit is negative, as expected, and is robust in magnitude and significantly different from zero in all specifications. This variable varies by age as well as by birth year and education, and this additional variation seems to provide a robust source of identification. The implied elasticity of the LFPR with respect to the SSDI benefit is -.10 at the means, based on the results in column 4. Average lifetime monthly earnings (AME) is estimated to have a positive impact on LFP in the first four columns, significantly different from zero. The sign of the AME effect on LFP is ambiguous in the context of our approximate decision rule specification; AME could capture a wealth effect, in which case we would expect a negative sign, but it could also be correlated with higher future wages, implying a positive effect if the value of working in the future is positively associated with the value of working today. The magnitude of the effect is robust across the first four specifications, and implies an elasticity of LFP in the range of 0.10 to 0.21 .

It is clear from the comparisons in Table 1 that identification of the effects of Social Security retirement benefits depends on the specification of birth cohort effects. Although all of the Social Security effects are identified in principle even with the 
inclusion of a full set of birth year fixed effects, there is insufficient variation in practice to permit reliable estimates of all of the relevant effects. ${ }^{12}$ We discount the results in the last column as implausible due to lack of identification, and in simulations discussed below we compare the results from the first four columns. The fact that the specification in the fourth column, with two-year birth cohort effects, cannot be rejected against the specification in the last column provides justification for ignoring the results in the last column.

An alternative approach to identification of the Social Security effects is to drop the assumption of perfect foresight. As discussed above, it is difficult to determine an alternative to perfect foresight that would be a reasonable assumption over the entire 1962-2005 period. We report results based on an extreme alternative to perfect foresight, namely complete myopia. The advantage of this assumption is that in some cases Social Security benefits vary by calendar year as well as birth year and education. Table 2 shows the coefficient estimates on the Social Security variables for the same five specifications as in Table 1, using the assumption of complete myopia to calculate benefits. The results are surprising: all three SSB retirement variables have effects that are the opposite of our expectations based on the model described above. The effect of $S S B_{\text {nra }}$ is positive and significantly different from zero in all five columns, with effect sizes that increase with richer controls for birth year. The gain in SSB from retiring at age 70 instead of the $n r a$ has a negative effect on LFP that increases in magnitude and becomes significantly different from zero as richer controls for birth year are added. A higher age-62 benefit (which implies a smaller early retirement penalty) is associated with higher LFP, and the magnitude of the effect again increases across the columns. The effect of AME is also negative and robust across the columns. The results for the SSB variables are difficult to interpret. The assumption of myopia introduces an additional source of variation in the SSB variables: within birth cohort variation over time due to unanticipated benefit changes. This yields more precise estimates, but the pattern of the effects is inconsistent with our expectations. It is also difficult to understand why the effect sizes are larger with richer controls for birth year effects. One possible explanation for these results is that there were many rule changes in the 1960s

\footnotetext{
${ }^{12}$ This pattern of findings persists in more parsimonious specifications that include only one SSB variable.
} 
and early 1970s that increased the generosity of benefits. Moffitt (1987) points out that the assumption of myopia during this period is rather implausible since it implies that each of the many changes is assumed to be the last one that will ever occur. The same argument could be made for the 1980s as well. Krueger and Pischke (1992) assume myopic expectations about Social Security rule changes, and they also find results that are quite sensitive to specification and often counterintuitive.

The effects of other variables are less sensitive to the specification of birth year effects. The own log-wage effects in Table 1 are positive, as expected, and significantly different from zero. The estimates imply an elasticity of LFP with respect to the wage rate of about 0.20 at the observed mean LFPR of 0.608 . The wife's log-wage effect is also positive but quite small and insignificantly different from zero. Thus there is no evidence that rising wages of women have induced older men to remain in the labor force longer. DB pension coverage is estimated to have very small and insignificant effects on LFP of older men. DC pension coverage has a small positive effect on LFP, insignificantly different from zero. EPRHI coverage has a very small effect on LFP in all specifications. Bad health has a large and precisely estimated negative impact on LFP in all specifications, and the magnitude of the effect is robust across the columns. Married and previously married men are much more likely to be in the labor force than their never-married counterparts. Education has positive but surprisingly small effects on LFP, compared to the large raw differences shown in Figure 5. The large raw education gap in LFP is "accounted for" in the regression mainly by the wage rate. There is no difference in the LFPR of black and white men after controlling for the other variables in the regression. There is a 10 percentage point gap in the raw data in favor of whites, which is mainly accounted for by education. ${ }^{13}$

\section{B. Counterfactual Simulations}

The main issue of interest is how the results can be used to account for the

\footnotetext{
${ }^{13}$ In other specifications not reported here, we included the proportion of men working in manual occupations and the proportion self-employed, in order to determine whether physical demands of work at older ages and the greater control over working conditions provided by self-employment affect the LFPR. Manual workers are estimated to have a higher LFPR than their white collar counterparts, contrary to our expectation, but the effect is quite small after controlling for birth year effects. The fraction of men selfemployed is associated with a higher LFPR, but virtually the entire effect is eliminated with controls for birth year effects.
} 
observed LFP trends. We use the results to simulate several counterfactual experiments, in order to determine which, if any, of the explanatory variables can account for the trends. Figure 14 shows the result of an experiment in which Social Security retirement rules are fixed at their 1978 values while other variables take on their actual values. ${ }^{14}$ We picked the 1978 rules because these were among the most generous rules in the history of Social Security for men claiming benefits at the normal retirement age or earlier. Benefit amounts were increasing prior to 1978, and subsequent reforms have reduced the generosity of Social Security benefits. If changes to Social Security benefits are an important contributor to the downward LFP trend, then fixing benefits at their 1978 level should result in a much flatter LFP trajectory. Figure 14 shows the results of simulations based on the first and fourth specifications in Table 1. The simulated counterfactual trajectory based on the no-birth-year-effects specification (Table 1, column 1) is in fact somewhat flatter than the baseline trajectory, but the trajectory based on the two-yearbirth-cohort-effects specification is virtually identical to the baseline case using the observed changes in SS rules. According to these results, the decline in LFP from the early 1960s through the end of the 1980s would have occurred even if there had been no changes in Social Security retirement rules. This result is not an artifact of the specific choice of SS rules; using the rules for other years yields the same finding.

The simulation results are quantified in Table 3, which shows that the mean LFPR at ages 55-69 declined by 18.4 percentage points between 1966-70 and 1988-92. The predicted decline in the LFPR generated by our model, given the observed changes in the explanatory variables during this period, is also 18.4 percentage points for three of the four specifications. Table 3 shows that changes in Social Security retirement benefit rules can account for 19\% of the observed decline in the LFPR using the no-birth-yeareffects specification, but only $4 \%$ using the two-year-birth-cohort-effects specification. Changes in the rules governing the SSDI benefit can explain 5-7\% of the decline in older male LFP during this period. Changes in average lifetime earnings since 1970 did not contribute at all to the downward trend in LFP: the simulations indicate that if average lifetime earnings had remained constant at the 1970 level, the downward trend would

\footnotetext{
${ }^{14}$ Benefits are computed for each cohort as if they turn 62 in 1978 (birth year 1916), but using their actual earnings history. This allows us to capture the effect of rule changes while holding earnings constant.
} 
have been even stronger than the observed trend. Finally, the table shows that the calendar year and birth year effects can "explain" virtually all the downward trend in the LFPR from 1966-70 to $1988-92 .{ }^{15}$

Counterfactual simulation results for the other explanatory variables were very similar across all of the different specifications, so results are shown in Table 4 only for the specification with two-year birth year dummies. None of these other variables can account for more than a tiny fraction of the decline in LFP.

We now use our estimates to analyze the increase in the older male LFPR in recent years. Table 5 shows that the LFPR increased by 4.7 percentage points between 1988-92 and 2001-05, and our model predicts exactly this increase given the observed changes in the explanatory variables. We find that the observed increase in LFP can be entirely explained by changes in the education distribution, and this finding is robust across the alternative regression specifications. More educated men participate in the labor force at higher rates (see Figure 5), and the proportion of older men with some college or a four year college degree has increased significantly since the mid 1980s (see Figure 4). Figure 15 shows the implications of our estimates: if the education distribution of the older male labor force was fixed at its 1985 level, LFP would have continued to decline in the 1990s and 2000s rather than increase. This finding is robust to dropping the assumption of perfect foresight with respect to Social Security rules and replacing it with the assumption of myopic expectations. Table 5 shows that changes in other explanatory variables either go in the wrong direction or account for only a modest proportion of the increase in LFP. Changing patterns of pension coverage can account for $2-11 \%$ of the increase depending on the specification. Calendar year and birth year effects appear to be moderately important in some specifications, but the results are not robust. Changes in Social Security benefit rules in the 1980s and 1990s cannot explain any of the increase. Changes in own wages cannot explain any of the increase in male LFP, and changes in the wife's wage can explain $4-5 \%$ of the increase. ${ }^{16}$

\footnotetext{
${ }^{15}$ Simulation results based on the assumption of myopic expectations concerning Social Security benefits have very similar implications: changes in Social Security benefits cannot explain the decline in male LFP.

${ }^{16}$ We estimated models with the same specification as in Table 1 but using the LFPR of the wives of the married men as the dependent variable. These models show consistently positive and significant effects of wives' wages on their LFPR. This suggests that factors that caused increased LFP of older married women in recent years may have contributed to the increase in older male LFP, but the simulation results in Table 5
} 
We estimated additional models disaggregated by education, age, and calendar year, in order to determine whether there are any important differences in the effects of Social Security and other variables by education, age, and period. The estimated Social Security effects are quite similar across the four education groups. Counterfactual simulations based on these disaggregated estimates reveal consistent patterns across education groups: as in the pooled estimates, changes in Social Security can account for at most one fifth of the decline in LFP, and adding richer controls for birth year effects reduces the estimated impact of Social Security substantially. The effects are also similar across age groups (55-61, 62-64, 65-66, and 67-69) in the perfect foresight specification, but the myopic specification yields substantially different effects of Social Security by age. Specifically, the effects for ages 55-61 are similar to those reported in Table 2, while the effects for the three older age groups are more consistent with our prior expectations. However, the magnitudes of these effects are highly sensitive to specification, and many are implausibly large. Finally, estimates by period (1962-1988, 1989-2005) do not reveal any important differences in the effects of the key variables across periods.

\section{Reconciling results with the literature}

Our results imply that changes in Social Security benefits are not a major cause of either the decline in LFP of older men up to the 1980s, or the increase since the late 1990s. The finding for the decline is consistent with the results of Moffitt (1987), using time series data, and Krueger and Pischke (1992), who use synthetic panel data like ours. Blau (1994) used longitudinal data on individuals and found that Social Security is important in accounting for variation across individuals in the timing of labor force exit, but that trends over time in Social Security benefits could not explain much of the secular trend in the exit rate from the labor force over the period 1961-1979. Peracchi and Welch (1994) reached a similar conclusion, as did Burtless (1986), using longitudinal data.

However, Hurd and Boskin (1984) used longitudinal data on individuals for the period

suggest that the magnitude of such effects is very small. In addition, we estimated a specification in which the LFP status of the wife is included as an explanatory variable, similar to the approach used in Schirle (2007). The results show a strong positive association between the labor force participation of older men and their wives. A counterfactual simulation based on the estimate indicated that growth in labor force participation of older married women could explain about one quarter of the recent increase in older male labor force participation. This is virtually identical to Schirle’s result. 
1968-1973, and found that changes in Social Security benefits could explain the entire 8.2 percentage decrease in participation of men aged 59-67 during this period. Krueger and Pischke (1992) found different results for this period, using synthetic panel data: after accounting for calendar year fixed effects, Social Security benefits were found to have a small effect on LFP. We attempted to replicate the Krueger-Pischke analysis, by aggregating our data over education groups and re-estimating our model for the period 1967-1975 for ages 58-67. Including age and calendar year fixed effects and excluding birth year controls, like Krueger and Pischke, we find that changes in Social Security benefits cannot explain any of the decrease in LFP during this period. Controlling for a quadratic birth year trend, Social Security can explain $6 \%$ of the decline; and controlling for five year birth cohort effects, Social Security can explain 33\% of the decline. ${ }^{17}$ Thus the results are somewhat sensitive to specification, but they are closer to the findings of Krueger and Pishcke than to the findings of Hurd and Boskin.

Stewart (1995) used time series data through 1990 to update Moffitt’s (1987) analysis, and found that Social Security benefits could account for about $40 \%$ of the decline in LFP of men aged 62-64 and 65-69 from the early 1960s to 1990. We reestimated our model using data through 1990, aggregated over education. Social Security could explain as much as 19\% of the decline in LFP for men aged 65-69 in the specification with a quadratic birth year trend, but the other specifications yielded much smaller effects. At ages 62-64, Social Security could explain as much as $39 \%$ of the decline in the specification with two-year birth cohort effects, but again the effects were much smaller in the other specifications.

Pingle (2006) uses micro data from the SIPP for 1983-2003 to estimate the effect on the employment of older men of the increase in the DRC mandated by the 1983 Social Security Amendments. His findings indicate that each one percentage point increase in the DRC raised the employment rate of men aged $65-70$ by 1.5 percentage points and of men aged 60-70 by 1.8 percentage points. He does not present counterfactual simulation results, but one can use the results in his paper to infer that the increase in the DRC from

\footnotetext{
${ }^{17}$ Estimates with two-year and one-year birth year effects yielded implausible results, indicating lack of identification. Our specification is not the same as Krueger and Pischke, so we do not claim that this is a true replication effort, but the specifications are similar enough to make comparisons useful.
} 
3\% in 1983 to $6.5 \%$ in 2003 would be predicted by his model to have caused an increase in the employment rate of .0525 for men aged 65-69. The observed increase was .0641, so his model can explain $82 \%$ of the observed increase as resulting from the increase in the DRC. We used our estimates to simulate the effect of the increase in the DRC by comparing predicted LFP in the baseline case to the prediction in a counterfactual scenario in which the DRC is held constant at its 1983 level. Results from this experiment were quite sensitive to birth year controls. With no control for birth year, the DRC could explain $64 \%$ of the observed increase in LFP, but the effect falls monotonically with richer birth year controls, and is only $10 \%$ with two-year birth year effects. In order to provide a closer comparison to Pingle's approach, we aggregated our data over education groups and re-estimated our model using the same years and ages as Pingle. The results were again sensitive to birth year controls, but in this case the twoyear birth year effects specification (like the specification in Pingle's Table 4, column 4) were closer to Pingle's: the increase in the DRC can explain 139\% of the observed increase in LFP of men aged 65-69 and 74\% for men aged 62-64. Thus there is some evidence to support the DRC as an alternative to our educational composition explanation for the recent increase in LFP, but the results are not definitive.

Mastrobuoni (2006) uses micro data from the CPS to estimate the impact on LFP of older men and women of the increase in the nra mandated by the 1983 Social Security Amendments. ${ }^{18}$ He finds that for each two month increase in the nra from 65 to 66 , the age of retirement (derived from a model of non-participation in the labor force) rose by one month. Our results are not directly comparable, but we simulated a counterfactual scenario in which the $n r a$ is held constant at 65 for all cohorts, rather than increasing in two month increments beginning with cohorts that turned 62 in 2000. Without any birth year controls, the counterfactual simulation implies that the increase in the NRA can explain only $10 \%$ of the observed increase in LFP at older ages; with birth year controls, the effect falls to zero. Mastrobuoni's specification includes age and birth cohort effects but not calendar year effects. Mastrobuoni's model estimates the "treatment effect” of

\footnotetext{
${ }^{18}$ Duggan et al. (2005) investigate the effect of the increase in the NRA on SSDI enrollment, but they do not examine the effect on LFP. Pingle (2006) finds a positive effect of the increase in the NRA on employment of men aged 60 to 70, but not for men aged 65 to 70 . However, his estimate is implausibly
} 
raising the $n r a$, while we force the effect of changes in the nra to operate through benefits. Mastrobuoni suggests that changes in the nra may operate through noneconomic channels, such as changing social norms or the "focal" retirement age. His specification would pick up such effects while ours would not, thus potentially reconciling our estimate of a small effect of the nra with Mastrobuoni's large estimated effect. $^{19}$

\section{Robustness}

We briefly summarize here the findings from a number of alternative specifications. We repeated the analysis using an alternative measure of labor market attachment: weeks worked in the previous calendar year. The results were qualitatively very similar. We replaced Social Security benefits with Social Security wealth, computed using a standard approach, described in the Appendix. The simulated effects of counterfactual Social Security scenarios were very similar using this approach. We used alternative assumptions about year of birth in order to determine whether the results are sensitive to our assumption that all individuals have their birthdays after the March survey date. The alternatives were to assume that everyone had their birthday before the survey date, and to randomly assign $80 \%$ of the observations to have their birthday after the survey date and $20 \%$ before the survey date. The results were very similar using all three approaches. We used an after-tax measure of the wage rate, described in the Appendix, and found virtually identical results.

One potential problem with our education fixed effects specification is that the average skill of a given education group may decline as educational attainment increases. For example, the marginal college attendee today may have lower ability than in previous periods in which college attendance was less common. This would imply that education effects on LFP should not be treated as fixed. ${ }^{20}$ To address this possibility, we included

\footnotetext{
large: a one year increase in the NRA is estimated to increase employment by 6-13 percentage points (Table 6).

${ }^{19}$ Baker and Benjamin (1999) estimated the impact of a reduction in the age of eligibility for public pension benefits in Canada. Their approach is similar to Mastrobuoni's in the sense that they estimated the "treatment effect" of the change in age of eligibility. Their estimates indicate that reducing the age of eligibility increased the rate of benefit receipt but did not reduce labor force participation. They suggest that the marginal beneficiaries would have been out of the labor force anyway.

${ }^{20}$ We thank Mark Duggan for pointing this out to us.
} 
interactions between the education dummies and a linear time trend. The implied effects of education were quite sensitive to birth year effects in this alternative specification, in contrast to the results reported in Table 5. This suggests that our results attributing the recent increase in LFP to the changing education composition of the older male population may not be robust.

Finally, our model omits wealth. In order to determine whether the results are sensitive to this omission, we added two additional variables to the model. One is the capitalized value of income from interest, dividends, and rent (using a real return of $4 \%$ ). The other is a binary indicator of home ownership. These measures are available in the CPS on a consistent basis only from 1977 forward. The estimates show a very small effect of capitalized asset income on LFP, and a rather large negative effect of home ownership. Counterfactual simulation results indicate that changes in home ownership rates and in the capitalized value of asset income have had very little impact on the LFPR of older men.

\section{Conclusions}

We are unable to attribute the decline in LFP of older men from the 1960s through the 1980s to any of the main hypotheses investigated in this paper. Despite trends in benefit rules that suggest a potentially important role for Social Security, we find no evidence that Social Security played a significant role in explaining the decline. The specification with no controls for birth cohort effects implies that changes in the rules that govern Social Security retirement benefits can explain 19\% of the observed decline in LFP from the late 1960s through the late 1980s. The least restrictive specification in which Social Security effects are well determined (two-year birth cohort effects) implies that Social Security retirement benefits can explain only $4 \%$ of the observed decline in LFP. Changes in rules governing SSDI benefits can explain another $7 \%$ of the decline. Our results imply that the long run trend has occurred mainly as a result of unobserved changes in preferences, constraints, or institutions over time and across birth cohorts.

We find that the recent increase in the LFPR of older men can be accounted for by the changing educational composition of the older male labor force. Low-participating 
high school dropouts have been rapidly replaced in the older male population by higherparticipating college attendees and college graduates in recent years. This result is robust across most but not all of the specifications we estimated. Education is likely correlated with unobserved factors that influence preference for work, such as motivation. Men with higher levels of education also enter the labor force at later ages, so it is possible that these men work longer to reach retirement incentive milestones (e.g. tenure rules associated with DB plans) or may simply prefer to exit the labor force at later ages. We attribute a small role to the increases in the DRC, but in some specifications we are able to replicate Pingle's (2006) finding attributing a larger role to the DRC.

Our findings are consistent with those of several previous studies that have directly examined how changes over time in Social Security benefits have affected LFP trends (Burtless, 1986; Moffitt, 1987; Kruger and Pischke, 1992; Baker and Benjamin, 1999). Social Security incentives have been found to be powerful in explaining cross country variation in retirement patterns (Gruber and Wise, 2004) and in explaining variation in labor force behavior within cohorts (e.g. Hurd and Boskin, 1984; Blau, 1994; Rust and Phelan, 1997). In principle, these apparently contradictory results could be reconciled, depending on the relative magnitude of variation in Social Security benefits across countries, across individuals within a cohort, and across cohorts. Alternatively, some sources of variation in Social Security benefits may be more plausibly exogenous than others. Cross country differences in Social Security benefits and incentives may be confounded by unobserved differences across countries. Cross-individual variation in Social Security benefits can identify behavioral responses only because of the nonlinearity of the Social Security benefit rules. This is not a particularly attractive source of variation. Variation over cohorts in Social Security rules within a country may be the most plausibly exogenous source of variation available. If this is the case, then our estimates suggest that the true effect of Social Security on labor force participation at older ages is small. Of course, our results cannot answer the obvious next question of interest: if it is not changes in Social Security (or pensions, EPRHI, or lifetime earnings) that have caused such striking trends in labor force behavior at older ages, then what is responsible? 


\section{Appendix}

\section{A1. Social Security Benefits}

Our analysis requires measures of mean Social Security benefits by cohort. Cohorts are defined by birth year (1892 to 1949) and education group (less than high school; high school graduate; some college; college graduate). Cohort Social Security benefits are a function of Social Security regulations (which vary by birth year) and mean earnings history of each cohort (which varies by birth year and education group). Section A.1.1 details the methods used to construct earnings histories; Section A.1.2 describes how these earnings histories are used to compute cohort specific measures of monthly Social Security benefits; and section A.1.3 describes how monthly benefits are converted to measures of Social Security Wealth.

\section{A1.1 Cohort Specific Earnings Histories}

We construct mean earnings for each cohort at ages 27 through 57 using data from the March Current Population Survey (CPS) between 1962 and 2005 and from editions of the Annual Statistical Supplement published by the Social Security Administration (SSA) between 1973 and 2005. The SSA data contain median earnings of male workers by age group and year. We ignore earnings data for ages below 27 and above 57 to limit selection bias due to non-participation. We assume that earnings at ages 58 to 70 grow at the rate of the average annual wage as published in the SSA in years 2005 and earlier, and grow at 3\% in years 2006 and later. Because only 35 years of earnings are incorporated in the Social Security benefit computation, earnings at ages 26 and younger do not affect Social Security benefits of workers who work in every year from age 27 until retirement at ages 62 or older, assuming that earnings before age 26 are less than at older ages.

The SSA data are problematic for our purposes in at least three ways. First, median earnings are reported instead of mean earnings. To resolve this issue, we calculated the ratio of mean earnings to median earnings in the CPS. These ratios were used to convert the median earnings reported in the Annual Statistical Supplement to means. In the March supplements of the CPS from 1962 through the present, respondents report their earnings from the previous year. These data are used to calculate mean 
earnings, median earnings, and their ratio by age group for years 1961 through $2004^{21}$ We then use OLS to estimate models of the form $M M_{a y}=\alpha_{a 0}+\alpha_{a 1} y+\varepsilon_{a y}$, where $M M_{a y}$ is the mean-median ratio for age group $a$ in birth year $y$. The OLS estimates are used to generate a predicted value of $M M_{a y}$ for each age birth-year cell. Each value for median earnings reported in the Annual Statistical Supplement was then multiplied by the predicted value of the mean-median ratio for the corresponding age cell to create measures of mean earnings by age group and earnings year.

A second issue with our data is that values for some birth year and age cells are not available in the Annual Statistical Supplement. Earnings at age 27 are missing for birth years between 1910 and 1932; earnings at age 32 are missing for birth years between 1905 and 1927; earnings at age 37 are missing for birth years between 1900 and 1922; and so on. Further, we have no data on mean earnings at ages 28 to 31, 33 to 36, and so on for every cohort in our sample. We "fill in" the missing values using a two step procedure. First, we regress mean earnings on birth year $y$ separately by age $a$ using the model $\ln \left(E_{a y}\right)=\sum_{i=0}^{6} b_{i} y^{i}+\varepsilon_{a y}$. OLS estimates of this model allow us to generate predicted values of earnings at ages 27, 32, 37, 42, 47, 52, and 57 for all birth years. The predicted values from our estimates closely match the actual values, and the models generate reasonable predicted values for the earlier ages and birth years not included in the SSA tables. Next, we regress predicted mean earnings (from the previous step) on age separately for each birth year using the model $\hat{E}_{a y}=\sum_{j=0}^{4} \beta_{j y} a^{j}+\tau_{a y}$. OLS estimates of this model are used to generate predicted values of mean earnings for at all ages and birth years in our data, including ages 28 to 31, 33 to 36, and so on. OLS estimates of these models generate reasonable values of mean earnings at all ages and birth years. These two steps provide predicted values of mean earnings for each age and birth year cell in our sample.

\footnotetext{
${ }^{21}$ We capped reported earnings in the CPS at the Maximum Taxable earnings for that year based on appropriate Social Security regulations before computing means and medians by cell. To match the aggregation used by the SSA, we aggregated to the age groups reported in the Annual Statistical Supplement (25 - 29, $30-34$, and so on).
} 
The third issue with our data is that earnings are not reported separately by education level in the SSA. We need to disaggregate earnings histories by education group to compute cohort-specific measures of Social Security benefits. We use data from the CPS to accomplish this task. We compute the ratio of mean earnings for each education group to mean population earnings (the "earnings-ratio," denoted $\hat{E R_{y e}}$ ) in the CPS, separately by birth year ${ }^{22}$. Using this ratio, we compute estimates of mean earnings by birth year, age, and education group according to the formula $\hat{E}_{\text {aye }}=\hat{E}_{a y} * \hat{E R}_{y e}$, where $E$ is mean earnings, $a$ is age, $y$ is birth year, and $e$ is education group. To compute the earnings ratio, we calculate mean earnings from ages 27 to 57 separately by birth year for each education group and for all education groups, then divide the first by the second to create the birth year, education group specific earnings ratio ${ }^{23}$. We then computed predicted values of the earnings ratio from OLS estimates of the model $E R_{y e}=\sum_{k=0}^{3} a_{e k} y^{k}+\mu_{e y}$. Because we don't observe earnings prior to age 57 for birth years before 1906, we assume the earnings ratios for those birth years are constant at the 1906 level. The results verify that OLS estimates of our model do a reasonable job of predicting earnings ratios for each education group and birth year.

Because we do not compute earnings ratios for each cohort separately by age, our measure of the earnings ratio "averages out” life-cycle earnings patterns for each birth year. This creates biases for at least two reasons. First, the returns to schooling are higher at older ages, so for higher levels of education we overstate mean earnings at younger ages and understate mean earnings at older ages. The opposite is true for lower levels of education. Second, because we do not observe younger ages for earlier birth years in the CPS, and earnings for better educated men are relatively higher at later ages, we are overstating (understating) the ratio of mean earnings to population earnings for higher (lower) levels of education at earlier birth years.

\footnotetext{
${ }^{22}$ Ideally we could compute earnings-ratios separately for each education group by birth-year and age. However, because the CPS only goes back to 1962 we lack data on earnings at younger ages for earlier birth years. This makes it quite difficult to construct reasonable estimates of earnings by education group for these cells. However, when we include data from the 1940, 1950, and 1960 U.S. Census we will have data for some of these cells. This may enable us to construct birth year and age specific earnings ratios.

${ }^{23}$ We omit cells with sample size less than 30
} 
We should also note some limitations of using CPS data to calculate Social Security earnings histories. The CPS includes some workers who may not have been covered by Social Security, particularly in earlier years. In addition, the CPS data (generated from surveys) is likely subject to a higher degree of measurement error then the SSA data (generated from administrative records). To address this, we removed observations with suspect earnings data from our sample. We dropped all records where the real weekly wage (total earnings in the previous calendar year / number of weeks worked last year) was below $\$ 50$ and above $\$ 40,000$. This reduced the number of observations with positive earnings in our CPS sample by 2.8\% (18,881 records).

\section{A1.2 Computing Cohort Specific Social Security Benefits}

We use the earnings history generated for each birth year and education group cell to compute the monthly Social Security Benefit (SSB) conditional on claiming at age $t$, using cohort mean earnings at each age between 27 and age $t-1$, where $t$ is 62 , the NRA, or 70. Because the NRA has changed over time, the earnings history used to compute benefits conditional on claiming at the NRA varies by cohort. Although our data are annualized, we compute the SSB conditional on claiming benefits precisely at the age (in months) of the cohort-specific NRA. For cohorts born in 1942 and earlier, we include earnings from ages 27 through 64, and for cohorts born in 1943 and later we include earnings between ages 27 and 65 (because the NRA for the latter cohorts is 66) ${ }^{24}$.

We construct benefits under two alternative assumptions about future rule changes: perfect foresight and myopia. In both cases we assume that future earnings, future average annual wages used to index wages, and future inflation rates are known with perfect foresight. Computing benefits under the assumption of perfect foresight is equivalent to using the benefit rules in place at the assumed claim age. We use the ANYPIA benefit calculator provided by the Social Security Administration to compute SSB in this case ${ }^{25}$. Based on birth year and retirement age, the ANYPIA program computes the appropriate Primary Insurance Amount (PIA) and monthly benefit for a given earnings history. Under the assumption of perfect foresight there is no variation in

\footnotetext{
${ }^{24}$ Per Social Security rules, earnings in the year that Social Security benefits are claimed are ignored in the computation of PIA.

${ }^{25}$ The ANYPIA program is available on the Social Security Website at http://www.ssa.gov/OACT/ANYPIA/anypia.html
} 
the SSB by age for a given cohort.

Alternatively, under myopia we compute the expected SSB in year $t$ using the rules that, as of year $t$, are scheduled to be in place at the assumed claiming age. This assumption results in variation in the SSB by age for a given birth-year-education group cell if there were rule changes between year $t$ and the year in which the individual reaches the assumed claiming age. This variation is most significant in years up to and including the 1977 amendments when substantial rule changes were implemented with relatively little lead time. However, legislation passed in 1983 announced changes in the normal retirement age and the delayed retirement credit many years in advance. As a result these changes were known at earlier ages even under the assumption of myopia, resulting in very little variation in SSB by age in the later years of our sample. The ANYPIA program is unable to calculate expected SSB under myopia, so we wrote our own SAS code to do this.

\section{A1.3 Computing Social Security Wealth}

In an alternative empirical specification we replace monthly Social Security Benefits with Social Security Wealth, an estimate of the expected present discounted value of lifetime Social Security retirement benefits. Social Security Wealth is defined as $S S W_{i a}=\sum_{j=a}^{T} S S B_{i a}(1+r)^{a-j}$, where $S S B_{i a}$ is the monthly Social Security benefit awarded to cohort $i$ conditional on claim age $a$ ( $a=62, N R A, 70$ ); $T$ is life expectancy (in months) from age $a$, based on life tables published by the Social Security Administration; and $r$ is the monthly interest rate, here set at .167, or roughly $2 \%$ annually. We assume the individual survives with certainty to his expected age at death, $T$, in order to simplify the calculations.

\section{A1.4 Computing Cohort Specific Social Security Disability Insurance Benefits}

We use the ANYPIA program and the earnings history generated for each birth year and education group cell to compute the monthly Social Security Disability Insurance (SSDI) benefit. For each potential claim age $t$ we assume full time work through period $t-2$ and no work in period $t-1$ and $t$. Because SSDI benefits are converted to retirement benefits after reaching the normal retirement age, we set SSDI to 0 at ages greater than or equal to the NRA. The Social Security rules used to compute SSDI 
depends only on the year in which disability benefits are claimed, and not on the birth year.

\section{A2. Pensions and Employer-Provided Retiree health Insurance (EPRHI)}

Pension measures were derived from SIPP topical modules in the 1984 panel (wave 4), 1986 panel (wave 4), 1990 panel (wave 4), 1991 panel (wave 7), 1992 panel

(wave 4), 1996 panel (wave 7), and 2001 panel (wave 7). Other panels were excluded due to incompleteness of data or changes in questionnaire design. These data have small sample sizes for earlier birth years: those who were born in 1900 are 84 at the time of the first survey so there is likely to be significant mortality bias.

Different questions on pensions are asked depending on whether the respondent is currently working, has had a job in the past, has received a lump sum payment from a retirement plan, or is currently receiving retirement benefits (other than Social Security). We compute binary pension coverage indicators as follows:

-- Defined Benefit (DB): DB coverage is assumed if (a) the pension from the current job is a defined benefit plan, or (b) the respondent expects to receive pension benefits from a past job, or (c) the retirement benefits he is currently receiving are from a defined benefit type plan. Otherwise the respondent does not have a DB plan.

-- Defined Contribution (DC): DC coverage is assumed if (a) the pension from his current job is a defined contribution plan, or (b) he owns a business that has a pension plan he participates in, or (c) he is receiving retirement benefits from a defined contribution plan, or (d) he received a lump sum payment from a pension plan in the past. Otherwise the respondent does not have a DC plan.

A SIPP respondent is asked about EPHRI coverage only if he is currently receiving retirement benefits. The binary EPRHI coverage indicator is set to 1 if the SIPP respondent affirms that he has health coverage provided by a former employer, and 0 otherwise. 


\section{A3. Wages}

Wage rates are constructed from CPS data for the men in our sample and their spouses. The wage rate is defined as total earnings from wages and salary in the previous year divided by annual hours worked in the previous year. Annual hours is the product of weeks worked in the previous year and "hours usually worked per week in the previous year” for survey years 1976 and later. In years prior to 1976 annual hours is defined as the product of weeks worked in the previous year and hours worked in the week prior to the survey. We follow Blau and Kahn (2005) in the handling of top-coded values for earnings. Generally top-coded values are multiplied by a factor of 1.45 and included in the sample used to estimate the regression equation. Again following Blau and Kahn (2005), we convert all wages to real 2005 dollars and drop observations with hourly wages below \$2 and above \$200.

We only observe wages for those in our sample who choose to work. Therefore we replace observed wages with predicted log wages from regression equations estimated separately by birth year, sex, and education group. The wage equations include as regressors a quadratic in age and indicators for race (white, black, or other), marital status (married, once-married, never-married), geographic region (Northeast, Midwest, South, West), and metropolitan status.

The marginal tax rate is calculated for each individual in the CPS sample using the TAXSIM program provided by the National Bureau of Economic Research ${ }^{26}$. The marginal federal tax rate (MFTR) is computed based on labor earnings assuming fulltime work (2000 hours annually) at the predicted wage rate, observed earnings of the wife (if married), and income from interest, dividends, and net rentals. Payroll taxes for Old-Age, Survivors, and Disability Insurance (OASDI) and Hospital Insurance (HI) are applied to labor earnings (assuming full time work at the predicted wage rate) up to the maximum taxable earnings amount. The after-tax wage rate is the product of the predicted wage rate and $(1-\mathrm{MFTR}-(\mathrm{OASDI}+\mathrm{HI}))$.

\footnotetext{
${ }^{26}$ See http://www.nber.org/ taxsim/taxsim-calc7/index.html
} 


\section{References}

Anderson, Patricia M., Gustman, Alan L., and Steinmeier, Thomas L. "Trends in Male Labor Force Participation and Retirement: Some Evidence on the Role of Pensions and Social Security in the 1970s and 1980s." Journal of Labor Economics 17, no. 4 (Oct. 1999): 757-783.

Autor, David H. and Mark G. Duggan . "The Rise in the Disability Roles and the Decline in Unemployment,” Quarterly Journal of Economics 118 (1) (Feb. 2003): 157206.

Baker, Michael, and Dwayne Benjamin. "Early Retirement Provisions and the Labor Force Behavior of Older Men: Evidence from Canada,” Journal of Labor Economics 17, No. 4, Part 1 (October 1999): 724-56.

Benitez-Silva, Hugo; Buchinsky, Moshe; Chan, Hiu Man; Cheidvasser, Sofia; Rust, John. “How Large Is the Bias in Self-Reported Disability?” Journal of Applied Econometrics 19 (6) (2004): 649-670.

Blau, David M. “Labor Force Dynamics of Older Men.” Econometrica 62, No. 1 (Jan. 1994): 117-56.

Blau, David M. “Labor Force Dynamics of Older Married Couples.” Journal of Labor Economics 16, no. 3 (July 1998): 595-629.

Blau, David M. and Gilleskie, Donna B. "Retiree Health Insurance and the Labor Force Behavior of Older Men in the 1990s." The Review of Economics and Statistics 83 no. 1 (Feb. 2001): $64-80$.

Blau, Francine, and Lawrence Kahn. "Changes in the Labor Supply Behavior of Married Women: 1980-2000,” National Bureau of Economic Research Working Paper 11230, March 2005.

Burtless, Gary. "Social Security, Unanticipated Benefit Increases, and the Timing of Retirement,” Review of Economic Studies 53 (1986): 781-805.

Burtless, Gary, and Robert A. Moffitt . "The Joint Choice of Retirement Age and PostRetirement Hours of Work,” Journal of Labor Economics 3 (1985): 209-236.

Burtless, Gary and Quinn, Joseph F. "Retirement Trends and Policies to Encourage Work Among Older Americans.” Boston College Working Paper 436 (January 2000).

Bound, John. "The Health and Earnings of Rejected Disability Insurance Applicants," American Economic Review 89 (3) (June 1989): 482-503.

Chen, Susan, and Wilbert van der Klaauw. “The Effect of Disability Insurance on Labor 
Supply of Older Individuals in the 1990s,” Journal of Econometrics (in press)

Coile, Courtney. "Retirement Incentives and Couples' Retirement Decisions." Topics in Economic Analysis and Policy 4 (1) (2004), article17. www.bepress.com/bejeap/topics/vol4/iss1/art17

Costa, Dora L. The Evolution of Retirement: An American Economic History, 1880 1990. The University of Chicago Press (1998), Chicago, IL.

Costa, Dora L. "From Mill Town to Board Room: The Rise of Women's Paid Labor." The Journal of Economic Perspectives 14 (4) (Autumn, 2000): 101 - 122.

Diamond, Peter, and Hausman, Jerry. "The Retirement and Unemployment Behavior of Older Men.” In Henry Aaron and Gary Burtless (eds.) Retirement and Economic Behavior Washington D.C.: The Brookings Institution, 1984.

Duggan, Mark, Perry Singleton, and Jae Song. "Aching to Retire? The Rise in the Full Retirement Age and Its Impact on the Disability Rolls,” NBER Working Paper 11811, December 2005.

Employee Benefit Research Institute Website: Databook on Employee Benefits, Chapter 4: Participation in Employee Benefit Programs. Updated November 2005. http://www.ebri.org/publications/books/index.cfm?fa=databook

French, Eric. "The Effects of Health, Wealth, and Wages on Labour Supply and Retirement Behavior,” Review of Economic Studies 72 (2005): 395-427.

Friedberg, Leora. "The Labor Supply Effects of the Social Security Earnings Test,"Review of Economics and Statistics 82 (1) (Feb. 2000): 48-63.

Friedberg, Leora, and Webb, Anthony. "Retirement and the Evolution of Pension Structure.” Journal of Human Resources 40 (2) (Spring 2005): 281-308.

Gruber, Jonathan, and Wise, David A. (eds). Social Security and Retirement Around the World: Micro Estimation, University of Chicago Press for the NBER, 2004.

Gustman, Alan L., and Steinmeier, Thomas L. "Retirement in Dual-Career Families: A Structural Model.” Journal of Labor Economics 18 (3) (July 2000): 503 - 545.

Gustman, Alan L., and Steinmeier, Thomas L. "How Changes in Social Security Affect Retirement Trends,” Michigan Retirement Research Center Working Paper 2006127, September 2006.

Hurd, Michael D. “The Joint Retirement Decision of Husbands and Wives.” In David Wise (ed.) Issues in the Economics of Aging, Chicago: University of Chicago Press for the NBER, 1990: 231-258. 
Hurd, Michael D., and Boskin, Michael J. “The Effect of Social Security on Retirement in the Early 1970s.” The Quarterly Journal of Economics 99 (4) (Nov. 1984): $767-790$.

Kopecky, Karen. “The Trend in Retirement”, Economie d'avant garde, Research Report No. 12, University of Rochester, July 2005.

Krueger, Alan B., and Pischke, Jorn-Steffen. “The Effect of Social Security on Labor Supply: A Cohort Analysis of the Notch Generation.” Journal of Labor Economics 10 (4) (Oct. 1992): 412 - 437.

Lazear, Edward P., "Retirement from the Labor Force.” Handbook of Labor Economics, Vol 1. Ashenfelter, O. and Layard, R. eds., Elsevier Science, London (1986): 305-355.

Madrian, Brigitte C. “The Effect of Health Insurance on Retirement," Brookings Papers on Economic Activity, Microeconomics, 1 (1994): 181-232.

Mastrobuoni, Giovanni. "Labor Supply Effects of the Recent Social Security Benefit Cuts: Empirical Estimates Using Cohort Discontinuities,” CEPS Working Paper No. 136, Princeton University, December 2006.

Moen, Jon Roger, "Rural Nonfarm Households: Leaving the Farm and the Retirement of Older Men, 1860 - 1980.” Social Science History 18 (1) (1994): 55-76

Moffitt, Robert A. "Life Cycle Labor Supply and Social Security: A Time Series Analysis.” Work, Health, and Income among the Elderly, Burtless, Gary, ed., Brookings: Washington, D.C., 1987.

Parsons, Donald O. “The Decline in Male Labor Force Participation,” Journal of Political Economy 88 (Feb. 1980): 117-134.

Peracchi, Franco, and Welch, Finis. "Trends in Labor Force Transitions of Older Men and Women,” Journal of Labor Economics 12 (2) (April 1994): 210 - 242.

Pingle, Jonathan. “Social Security’s Delayed Retirement Credit and the Labor Supply of Older Men,” Working Paper, Board of Governors of the Federal Reserve, June 2006.

Quinn, Joseph F. “Has the Early Retirement Trend Reversed?” Working Paper 424, May 1999, Department of Economics, Boston College.

Rust, John. "Behavior of Male Workers at the End of the Life Cycle: An Empirical Analysis of States and Controls," David Wise (ed.) Issues in the Economics of Aging, Chicago: University of Chicago Press for the NBER, 1990: 317-379. 
Rust, John, and Christopher Phelan. "How Social Security and Medicare Affect Retirement Behavior in a World of Incomplete Markets,” Econometrica 65 (4) (July 1997): 781-832.

Schirle, Tammy. "Why Have the Labour Force Participation Rates of Older Men Increased Since the Mid-1990s?” Department of Economics Working Paper 200703 EC, Wilfred Laurier University, Waterloo, Canada, 2007.

Stewart, Jay, "Do Older Workers Respond to Changes in Social Security Benefits? A Look at the Time Series Evidence,” Bureau of Labor Statistics Working Paper 271, 1995. 
Table 1: Labor Force Participation Model Estimates

\begin{tabular}{|c|c|c|c|c|c|}
\hline & \multicolumn{5}{|c|}{ Birth Year Specification } \\
\hline & None & Quadratic & 5 Year & 2 Year & 1 Year \\
\hline SSBnra & $\begin{array}{l}-0.206 \\
(0.024)\end{array}$ & $\begin{array}{c}-0.168 \\
(0.025)\end{array}$ & $\begin{array}{c}-0.090 \\
(0.033)\end{array}$ & $\begin{array}{c}-0.052 \\
(0.051)\end{array}$ & $\begin{array}{c}\mathbf{0 . 2 0 1} \\
(0.099)\end{array}$ \\
\hline SSB62 - SSBnra & $\begin{array}{l}-0.046 \\
(0.023)\end{array}$ & $\begin{array}{c}0.015 \\
(0.027)\end{array}$ & $\begin{array}{l}-0.001 \\
(0.032)\end{array}$ & $\begin{array}{c}0.017 \\
(0.057)\end{array}$ & $\begin{array}{c}\mathbf{0 . 3 2 1} \\
(0.159)\end{array}$ \\
\hline SSB70 - SSBnra & $\begin{array}{c}\mathbf{0 . 1 2 2} \\
(0.018)\end{array}$ & $\begin{array}{c}\mathbf{0 . 0 8 2} \\
(0.020)\end{array}$ & $\begin{array}{c}\mathbf{0 . 0 6 1} \\
(0.024)\end{array}$ & $\begin{array}{c}0.027 \\
(0.037)\end{array}$ & $\begin{array}{l}-0.064 \\
(0.067)\end{array}$ \\
\hline Disability Benefit & $\begin{array}{c}-0.045 \\
(0.010)\end{array}$ & $\begin{array}{c}-0.065 \\
(0.013)\end{array}$ & $\begin{array}{c}-0.058 \\
(0.012)\end{array}$ & $\begin{array}{c}-0.065 \\
(0.013)\end{array}$ & $\begin{array}{l}-0.067 \\
(0.014)\end{array}$ \\
\hline AME & $\begin{array}{c}\mathbf{0 . 0 3 7} \\
(0.008)\end{array}$ & $\begin{array}{c}\mathbf{0 . 0 4 6} \\
(0.008)\end{array}$ & $\begin{array}{c}\mathbf{0 . 0 2 2} \\
(0.009)\end{array}$ & $\begin{array}{c}\mathbf{0 . 0 2 4} \\
(0.011)\end{array}$ & $\begin{array}{l}-0.020 \\
(0.016)\end{array}$ \\
\hline In(own wage) & $\begin{array}{c}\mathbf{0 . 1 1 6} \\
(0.020)\end{array}$ & $\begin{array}{c}\mathbf{0 . 1 1 6} \\
(0.020)\end{array}$ & $\begin{array}{c}0.125 \\
(0.021)\end{array}$ & $\begin{array}{c}\mathbf{0 . 1 2 0} \\
(0.021)\end{array}$ & $\begin{array}{c}0.129 \\
(0.022)\end{array}$ \\
\hline In(spouse's wage) & $\begin{array}{c}0.016 \\
(0.018)\end{array}$ & $\begin{array}{c}0.015 \\
(0.018)\end{array}$ & $\begin{array}{c}0.014 \\
(0.018)\end{array}$ & $\begin{array}{c}0.018 \\
(0.019)\end{array}$ & $\begin{array}{c}0.020 \\
(0.019)\end{array}$ \\
\hline DB Pension & $\begin{array}{l}-0.035 \\
(0.023)\end{array}$ & $\begin{array}{c}0.005 \\
(0.024)\end{array}$ & $\begin{array}{l}-0.014 \\
(0.025)\end{array}$ & $\begin{array}{l}-0.017 \\
(0.026)\end{array}$ & $\begin{array}{c}-0.022 \\
(0.027)\end{array}$ \\
\hline DC Pension & $\begin{array}{c}0.061 \\
(0.042)\end{array}$ & $\begin{array}{c}0.026 \\
(0.042)\end{array}$ & $\begin{array}{c}0.050 \\
(0.043)\end{array}$ & $\begin{array}{c}0.020 \\
(0.045)\end{array}$ & $\begin{array}{c}0.076 \\
(0.049)\end{array}$ \\
\hline EPRHI & $\begin{array}{c}0.015 \\
(0.021)\end{array}$ & $\begin{array}{c}0.004 \\
(0.021)\end{array}$ & $\begin{array}{c}0.009 \\
(0.021)\end{array}$ & $\begin{array}{c}0.002 \\
(0.023)\end{array}$ & $\begin{array}{l}-0.003 \\
(0.026)\end{array}$ \\
\hline Bad Health & $\begin{array}{c}-0.294 \\
(0.030)\end{array}$ & $\begin{array}{c}-0.319 \\
(0.030)\end{array}$ & $\begin{array}{c}-0.299 \\
(0.030)\end{array}$ & $\begin{array}{c}-0.306 \\
(0.030)\end{array}$ & $\begin{array}{c}-0.294 \\
(0.031)\end{array}$ \\
\hline Married & $\begin{array}{c}\mathbf{0 . 1 8 3} \\
(0.042)\end{array}$ & $\begin{array}{c}\mathbf{0 . 2 1 3} \\
(0.042)\end{array}$ & $\begin{array}{c}\mathbf{0 . 1 9 5} \\
(0.041)\end{array}$ & $\begin{array}{c}\mathbf{0 . 2 0 5} \\
(0.042)\end{array}$ & $\begin{array}{c}\mathbf{0 . 2 1 8} \\
(0.042)\end{array}$ \\
\hline Previously Married & $\begin{array}{c}\mathbf{0 . 1 6 7} \\
(0.049)\end{array}$ & $\begin{array}{c}\mathbf{0 . 1 7 5} \\
(0.048)\end{array}$ & $\begin{array}{c}\mathbf{0 . 1 6 3} \\
(0.048)\end{array}$ & $\begin{array}{c}\mathbf{0 . 1 6 9} \\
(0.049)\end{array}$ & $\begin{array}{c}\mathbf{0 . 1 8 2} \\
(0.050)\end{array}$ \\
\hline High School & $\begin{array}{c}\mathbf{0 . 0 2 6} \\
(0.008)\end{array}$ & $\begin{array}{c}\mathbf{0 . 0 1 7} \\
(0.008)\end{array}$ & $\begin{array}{c}0.016 \\
(0.008)\end{array}$ & $\begin{array}{c}0.015 \\
(0.008)\end{array}$ & $\begin{array}{c}0.012 \\
(0.009)\end{array}$ \\
\hline Some College & $\begin{array}{c}\mathbf{0 . 0 4 1} \\
(0.011)\end{array}$ & $\begin{array}{c}\mathbf{0 . 0 2 8} \\
(0.011)\end{array}$ & $\begin{array}{c}\mathbf{0 . 0 2 8} \\
(0.011)\end{array}$ & $\begin{array}{c}\mathbf{0 . 0 2 5} \\
(0.012)\end{array}$ & $\begin{array}{c}0.018 \\
(0.013)\end{array}$ \\
\hline College & $\begin{array}{c}\mathbf{0 . 0 5 3} \\
(0.017)\end{array}$ & $\begin{array}{c}\mathbf{0 . 0 3 6} \\
(0.018)\end{array}$ & $\begin{array}{c}\mathbf{0 . 0 4 0} \\
(0.019)\end{array}$ & $\begin{array}{c}\mathbf{0 . 0 3 9} \\
(0.019)\end{array}$ & $\begin{array}{c}0.038 \\
(0.021)\end{array}$ \\
\hline Black & $\begin{array}{c}0.003 \\
(0.039)\end{array}$ & $\begin{array}{c}0.013 \\
(0.039)\end{array}$ & $\begin{array}{l}-0.006 \\
(0.039)\end{array}$ & $\begin{array}{c}0.004 \\
(0.040)\end{array}$ & $\begin{array}{l}-0.013 \\
(0.040)\end{array}$ \\
\hline Constant & $\begin{array}{c}\mathbf{0 . 5 9 0} \\
(0.069)\end{array}$ & $\begin{array}{l}357.137 \\
(67.175)\end{array}$ & $\begin{array}{c}\mathbf{0 . 5 2 2} \\
(0.075)\end{array}$ & $\begin{array}{c}\mathbf{0 . 5 0 6} \\
(0.079)\end{array}$ & $\begin{array}{c}\mathbf{0 . 5 1 0} \\
(0.079)\end{array}$ \\
\hline Birth Year & & $\begin{array}{c}-0.366 \\
(0.070)\end{array}$ & & & \\
\hline Birth Year Squared & & $\begin{array}{c}0.009 \\
(0.002)\end{array}$ & & & \\
\hline $\begin{array}{l}\text { R Squared } \\
\text { P-Values }\end{array}$ & 0.962 & 0.963 & 0.963 & 0.964 & 0.964 \\
\hline $\begin{array}{l}\text { SS Benefits } \\
\text { Specification }\end{array}$ & $\begin{array}{c}0.0000 \\
-\end{array}$ & $\begin{array}{l}0.0000 \\
0.0000\end{array}$ & $\begin{array}{c}0.0000 \\
-\end{array}$ & $\begin{array}{c}0.0000 \\
-\end{array}$ & $\begin{array}{l}0.0001 \\
0.1752\end{array}$ \\
\hline
\end{tabular}

Notes: OLS estimates with robust standard errors, 2453 observations.

All specifications include age and calendar year dummies.

Estimates in bold are significantly different than zero at the $5 \%$ level.

Social Security retirement benefits are computed under the assumption of perfect foresight.

Monthly Social Security benefits and AME are measured in year 2005 dollars and divided by 1000 .

"P-Value: SS Benefits" is from a test of the hypothesis that the coefficients on the four Social Security variables and AME are all equal to zero.

"P-Value: Specification" is from $\mathrm{F}$ test against the specification in the previous column. 
Table 2: Additional Labor Force Participation Model Estimates

\begin{tabular}{|l|ccccc|}
\hline & \multicolumn{5}{|c|}{ Birth Year Specification } \\
& None & Quadratic & 5 Year & 2 Year & 1 Year \\
\hline SSBnra & $\mathbf{0 . 1 4 0}$ & $\mathbf{0 . 1 3 1}$ & $\mathbf{0 . 1 6 8}$ & $\mathbf{0 . 2 4 6}$ & $\mathbf{0 . 2 7 4}$ \\
& $(0.017)$ & $(0.017)$ & $(0.020)$ & $(0.020)$ & $(0.021)$ \\
SSB62 - SSBnra & $\mathbf{0 . 0 8 9}$ & $\mathbf{0 . 1 0 1}$ & $\mathbf{0 . 1 2 3}$ & $\mathbf{0 . 2 6 8}$ & $\mathbf{0 . 3 0 1}$ \\
& $(0.021)$ & $(0.022)$ & $(0.028)$ & $(0.031)$ & $(0.032)$ \\
SSB70 - SSBnra & -0.009 & -0.018 & $-\mathbf{0 . 0 3 7}$ & $-\mathbf{0 . 0 8 5}$ & $-\mathbf{0 . 1 2 0}$ \\
& $(0.013)$ & $(0.014)$ & $(0.016)$ & $(0.019)$ & $(0.022)$ \\
AME & $-\mathbf{0 . 0 3 7}$ & $\mathbf{- 0 . 0 2 9}$ & $\mathbf{- 0 . 0 2 6}$ & $\mathbf{- 0 . 0 2 5}$ & $-\mathbf{0 . 0 3 4}$ \\
& $(0.006)$ & $(0.007)$ & $(0.007)$ & $(0.007)$ & $(0.008)$ \\
R Squared & & & & & \\
P-Values & 0.962 & 0.962 & 0.964 & 0.966 & 0.967 \\
$\quad$ SS Benefits & & & & & \\
Specification & 0.0000 & 0.0000 & 0.0000 & 0.0000 & 0.0000 \\
\hline
\end{tabular}

Notes: OLS estimates with robust standard errors, 2453 observations.

All specifications include age and calendar year dummies.

Estimates in bold are significantly different than zero at the $5 \%$ level.

Social Security retirement benefits are computed under the assumption of myopia.

Monthly Social Security benefits and AME are measured in year 2005 dollars and divided by 1000 .

"P-Value: SS Benefits" is from a test of the hypothesis that the coefficients on the four

Social Security variables and AME are all equal to zero.

"P-Value: Specification" is from F test against the specification in the previous column. 
Table 3: Selected Counterfactual Simulations to Explain the Decline in Labor Force Participation, 1966-70 to 1988-92

(a) No Birth Cohort Effects

\begin{tabular}{|l|c|c|c|c|c|c|}
\hline & $\begin{array}{c}\text { Actual } \\
\text { LFPR }\end{array}$ & $\begin{array}{c}\text { Predicted } \\
\text { LFPR }\end{array}$ & $\begin{array}{c}\text { Social } \\
\text { Security } \\
\text { Retirement }\end{array}$ & $\begin{array}{c}\text { Social } \\
\text { Security } \\
\text { Disability }\end{array}$ & $\begin{array}{c}\text { Average } \\
\text { Lifetime } \\
\text { Earnings }\end{array}$ & $\begin{array}{c}\text { Calendar } \\
\text { and Birth } \\
\text { Year }\end{array}$ \\
\hline 1966 to 1970 & 73.0 & 72.9 & 70.6 & 71.9 & 72.9 & 72.8 \\
1988 to 1992 & 54.6 & 54.6 & 55.7 & 54.4 & 49.8 & 70.9 \\
Decrease & 18.4 & 18.4 & 15.0 & 17.4 & 23.1 & 1.9 \\
Difference & & & 3.4 & 0.9 & -4.7 & 16.5 \\
\% of Decrease & & & $19 \%$ & $5 \%$ & $-26 \%$ & $90 \%$ \\
\hline
\end{tabular}

(b) Quadratic Birth Cohort Effects

\begin{tabular}{|l|c|c|c|c|c|c|}
\hline & $\begin{array}{c}\text { Actual } \\
\text { LFPR }\end{array}$ & $\begin{array}{c}\text { Predicted } \\
\text { LFPR }\end{array}$ & $\begin{array}{c}\text { Social } \\
\text { Security } \\
\text { Retirement }\end{array}$ & $\begin{array}{c}\text { Social } \\
\text { Security } \\
\text { Disability }\end{array}$ & $\begin{array}{c}\text { Average } \\
\text { Lifetime } \\
\text { Earnings }\end{array}$ & $\begin{array}{c}\text { Calendar } \\
\text { and Birth } \\
\text { Year }\end{array}$ \\
\hline 1966 to 1970 & 73.0 & 72.9 & 70.7 & 71.4 & 72.9 & 72.3 \\
1988 to 1992 & 54.6 & 54.6 & 54.9 & 54.4 & 48.8 & 71.7 \\
Decrease & 18.4 & 18.4 & 15.8 & 17.0 & 24.2 & 0.6 \\
Difference & & & 2.6 & 1.4 & -5.8 & 17.8 \\
\% of Decrease & & & $14 \%$ & $7 \%$ & $-31 \%$ & $97 \%$ \\
\hline
\end{tabular}

(c) 5 Year Birth Cohort Effects

\begin{tabular}{|l|c|c|c|c|c|c|}
\hline & $\begin{array}{c}\text { Actual } \\
\text { LFPR }\end{array}$ & $\begin{array}{c}\text { Predicted } \\
\text { LFPR }\end{array}$ & $\begin{array}{c}\text { Social } \\
\text { Security } \\
\text { Retirement }\end{array}$ & $\begin{array}{c}\text { Social } \\
\text { Security } \\
\text { Disability }\end{array}$ & $\begin{array}{c}\text { Average } \\
\text { Lifetime } \\
\text { Earnings }\end{array}$ & $\begin{array}{c}\text { Calendar } \\
\text { and Birth } \\
\text { Year }\end{array}$ \\
\hline 1966 to 1970 & 73.0 & 73.0 & 72.1 & 71.6 & 73.0 & 71.5 \\
1988 to 1992 & 54.6 & 54.6 & 55.0 & 54.4 & 51.7 & 70.6 \\
Decrease & 18.4 & 18.4 & 17.1 & 17.2 & 21.2 & 0.9 \\
Difference & & & 1.3 & 1.2 & -2.8 & 17.5 \\
\% of Decrease & & & $7 \%$ & $7 \%$ & $-15 \%$ & $95 \%$ \\
\hline
\end{tabular}

\section{(d) 2 Year Birth Cohort Effects}

\begin{tabular}{|l|c|c|c|c|c|c|}
\hline & $\begin{array}{c}\text { Actual } \\
\text { LFPR }\end{array}$ & $\begin{array}{c}\text { Predicted } \\
\text { LFPR }\end{array}$ & $\begin{array}{c}\text { Social } \\
\text { Security } \\
\text { Retirement }\end{array}$ & $\begin{array}{c}\text { Social } \\
\text { Security } \\
\text { Disability }\end{array}$ & $\begin{array}{c}\text { Average } \\
\text { Lifetime } \\
\text { Earnings }\end{array}$ & $\begin{array}{c}\text { Calendar } \\
\text { and Birth } \\
\text { Year }\end{array}$ \\
\hline 1966 to 1970 & 73.0 & 73.0 & 72.3 & 71.4 & 73.0 & 72.0 \\
1988 to 1992 & 54.6 & 54.6 & 54.6 & 54.4 & 51.6 & 72.0 \\
Decrease & 18.4 & 18.4 & 17.7 & 17.0 & 21.4 & 0.0 \\
Difference & & & 0.7 & 1.4 & -3.0 & 18.4 \\
\% of Decrease & & & $4 \%$ & $7 \%$ & $-16 \%$ & $100 \%$ \\
\hline
\end{tabular}

Notes: Counterfactual values for $\mathrm{SSB}_{n r a}, \mathrm{SSB}_{62}$, and $\mathrm{SSB}_{70}$ are computed for each cohort using their actual earnings history and the Social Security rules in effect as if they turn 62 in 1978 (birth year 1916). Counterfactual Social Security Disability Insurance benefits are generated by computing SSDI for each cohort and age under the rules in effect in 1970. Counterfactual Average Lifetime Earnings are generated by assigning the average of AME between 1966 and 1970 to every cohort. The calendar year counterfactual value is 1968; the birth year counterfactual value is 1906 .

The "Social Security Retirement" counterfactual is the predicted LFPR where actual values for $\mathrm{SSB}_{n r a}, \mathrm{SSB}_{62}$, and $\mathrm{SSB}_{70}$ are replaced by their counterfactual values, and all other variables take on their actual values. Similarly, the "Social Security Disability", "Average Lifetime Earnings", "Calendar Year", and "Birth Year" counterfactual is the predicted LFPR where the variable of interest is replaced by its counterfactual value, and all other variables take on their actual values. 
Table 4: Additional Counterfactual Simulations to Explain the Decline in Labor Force Participation, 1966-70 to 1988-92

\begin{tabular}{|l|c|c|c|c|c|c|c|c|c|c|}
\hline & $\begin{array}{c}\text { Actual } \\
\text { LFPR }\end{array}$ & $\begin{array}{c}\text { Predicted } \\
\text { LFPR }\end{array}$ & Black & $\begin{array}{c}\text { Marital } \\
\text { Status }\end{array}$ & Health & Pensions & EPRHI & $\begin{array}{c}\text { Own } \\
\text { Wage }\end{array}$ & $\begin{array}{c}\text { Spouse's } \\
\text { Wage }\end{array}$ & Education \\
\hline 1966 to 1970 & 73.0 & 73.0 & 73.0 & 73.0 & 72.9 & 73.0 & 73.0 & 73.0 & 73.0 & 69.3 \\
1988 to 1992 & 54.6 & 54.6 & 54.5 & 54.6 & 54.3 & 54.6 & 54.6 & 55.5 & 54.7 & 49.2 \\
Decrease & 18.4 & 18.4 & 18.4 & 18.3 & 18.6 & 18.4 & 18.4 & 17.4 & 18.3 & 20.2 \\
Difference & & & 0.0 & 0.1 & -0.2 & 0.0 & 0.0 & 1.0 & 0.1 & -1.8 \\
\% of Decrease & & & $0 \%$ & $0 \%$ & $-1 \%$ & $0 \%$ & $0 \%$ & $5 \%$ & $1 \%$ & $-10 \%$ \\
\hline
\end{tabular}

Notes: $\quad$ The counterfactual value for each variable of interest is its average value between 1966 and 1970 . Counterfactual LFPR is the predicted value (based on coefficient estimates from the specification with 2 year birth cohort effects) where the variable of interest is replaced by its counterfactual value, and all other values take on their actual values. 
Table 5: Selected Counterfactual Simulations to Explain the Increase in Labor Force Participation, 1988-92 to 2001-05

(a) No Birth Cohort Effects

\begin{tabular}{|c|c|c|c|c|c|c|c|c|c|c|c|c|c|c|}
\hline & $\begin{array}{c}\text { Actual } \\
\text { LFP }\end{array}$ & $\begin{array}{c}\text { Predicted } \\
\text { LFP }\end{array}$ & Black & $\begin{array}{l}\text { Marital } \\
\text { Status }\end{array}$ & Health & Pensions & EPRHI & $\begin{array}{c}\text { Own } \\
\text { Wage }\end{array}$ & $\begin{array}{c}\text { Spouse's } \\
\text { Wage }\end{array}$ & \begin{tabular}{|l|} 
Average \\
Lifetime \\
Earnings \\
\end{tabular} & \begin{tabular}{|c|} 
Social \\
Security \\
Retirement \\
\end{tabular} & \begin{tabular}{|c|} 
Social \\
Security \\
Disability \\
\end{tabular} & \begin{tabular}{|c|c|}
$\begin{array}{c}\text { Calendar } \\
\text { and Birth } \\
\text { Year }\end{array}$ \\
\end{tabular} & Education \\
\hline 1988 to 1992 & 54.6 & 54.6 & 54.6 & 54.6 & 54.6 & 54.6 & 54.6 & 54.6 & 54.6 & 54.6 & 54.4 & 54.6 & 54.6 & 53.4 \\
\hline 2001 to 2005 & 59.2 & 59.2 & 59.2 & 59.5 & 59.7 & 58.7 & 59.3 & 59.2 & 59.0 & 58.5 & 60.4 & 60.1 & 59.5 & 52.4 \\
\hline Increase & 4.7 & 4.7 & 4.7 & 4.9 & 5.1 & 4.1 & 4.7 & 4.7 & 4.5 & 4.0 & 6.0 & 5.6 & 4.8 & -0.9 \\
\hline Difference & & & 0.0 & -0.2 & -0.5 & 0.6 & 0.0 & 0.0 & 0.2 & 0.7 & -1.3 & -0.9 & -0.2 & 5.6 \\
\hline$\%$ of Increase & & & $0 \%$ & $-5 \%$ & $-10 \%$ & $13 \%$ & $-1 \%$ & $0 \%$ & $4 \%$ & $15 \%$ & $-28 \%$ & $-19 \%$ & $-3 \%$ & $120 \%$ \\
\hline
\end{tabular}

\section{(b) Quadratic Birth Cohort Effects}

\begin{tabular}{|c|c|c|c|c|c|c|c|c|c|c|c|c|c|c|}
\hline & $\begin{array}{c}\text { Actual } \\
\text { LFP }\end{array}$ & $\begin{array}{c}\text { Predicted } \\
\text { LFP }\end{array}$ & Black & $\begin{array}{l}\text { Marital } \\
\text { Status }\end{array}$ & Health & Pensions & EPRHI & $\begin{array}{l}\text { Own } \\
\text { Wage }\end{array}$ & $\begin{array}{c}\text { Spouse's } \\
\text { Wage }\end{array}$ & $\begin{array}{l}\text { Average } \\
\text { Lifetime } \\
\text { Earnings }\end{array}$ & $\begin{array}{c}\text { Social } \\
\text { Security } \\
\text { Retirement }\end{array}$ & \begin{tabular}{|c|} 
Social \\
Security \\
Disability
\end{tabular} & $\begin{array}{c}\text { Calendar } \\
\text { and Birth } \\
\text { Year }\end{array}$ & Education \\
\hline 1988 to 1992 & 54.6 & 54.6 & 54.6 & 54.6 & 54.6 & 54.6 & 54.6 & 54.6 & 54.6 & 54.6 & 54.3 & 54.6 & 54.2 & 53.4 \\
\hline 2001 to 2005 & 59.2 & 59.2 & 59.2 & 59.6 & 59.7 & 59.1 & 59.2 & 59.2 & 59.0 & 58.4 & 61.4 & 60.5 & 57.5 & 52.3 \\
\hline Increase & 4.7 & 4.7 & 4.6 & 5.0 & 5.2 & 4.6 & 4.7 & 4.7 & 4.5 & 3.8 & 7.1 & 5.9 & 3.3 & -1.1 \\
\hline Difference & & & 0.0 & -0.3 & -0.5 & 0.1 & 0.0 & 0.0 & 0.2 & 0.8 & -2.4 & -1.3 & 1.4 & 5.7 \\
\hline$\%$ of Increase & & & $0 \%$ & $-7 \%$ & $-11 \%$ & $2 \%$ & $0 \%$ & $0 \%$ & $4 \%$ & $18 \%$ & $-52 \%$ & $-27 \%$ & $29 \%$ & $123 \%$ \\
\hline
\end{tabular}

\section{(c) 5 Year Birth Cohort Effects}

\begin{tabular}{|c|c|c|c|c|c|c|c|c|c|c|c|c|c|c|}
\hline & $\begin{array}{c}\text { Actual } \\
\text { LFP }\end{array}$ & $\begin{array}{c}\text { Predicted } \\
\text { LFP }\end{array}$ & Black & $\begin{array}{l}\text { Marital } \\
\text { Status }\end{array}$ & Health & Pensions & EPRHI & $\begin{array}{l}\text { Own } \\
\text { Wage }\end{array}$ & $\begin{array}{c}\text { Spouse's } \\
\text { Wage }\end{array}$ & $\begin{array}{l}\text { Average } \\
\text { Lifetime } \\
\text { Earnings }\end{array}$ & \begin{tabular}{c|} 
Social \\
Security \\
Retirement
\end{tabular} & \begin{tabular}{|c|} 
Social \\
Security \\
Disability
\end{tabular} & $\begin{array}{c}\text { Calendar } \\
\text { and Birth } \\
\text { Year }\end{array}$ & Education \\
\hline 1988 to 1992 & 54.6 & 54.6 & 54.6 & 54.6 & 54.6 & 54.6 & 54.6 & 54.6 & 54.6 & 54.6 & \begin{tabular}{|l|}
54.5 \\
\end{tabular} & \begin{tabular}{|l|}
54.6 \\
\end{tabular} & 55.0 & 53.3 \\
\hline 2001 to 2005 & 59.2 & 59.2 & 59.2 & 59.5 & 59.7 & 58.9 & 59.2 & 59.2 & 59.1 & 58.8 & 59.7 & 60.4 & 59.5 & 52.3 \\
\hline Increase & 4.7 & 4.7 & 4.7 & 5.0 & 5.1 & 4.3 & 4.7 & 4.7 & 4.5 & 4.3 & 5.3 & 5.8 & 4.5 & -1.0 \\
\hline Difference & & & 0.0 & -0.3 & -0.5 & 0.4 & 0.0 & 0.0 & 0.2 & 0.4 & -0.6 & -1.1 & 0.2 & 5.7 \\
\hline$\%$ of Increase & & & $0 \%$ & $-7 \%$ & $-10 \%$ & $8 \%$ & $0 \%$ & $0 \%$ & $4 \%$ & $9 \%$ & $-13 \%$ & $-24 \%$ & $4 \%$ & $122 \%$ \\
\hline
\end{tabular}

\section{(d) 2 Year Birth Cohort Effects}

\begin{tabular}{|c|c|c|c|c|c|c|c|c|c|c|c|c|c|c|}
\hline & $\begin{array}{l}\text { Actual } \\
\text { LFP }\end{array}$ & $\begin{array}{c}\text { Predicted } \\
\text { LFP }\end{array}$ & Black & $\begin{array}{l}\text { Marital } \\
\text { Status }\end{array}$ & Health & Pensions & EPRHI & $\begin{array}{c}\text { Own } \\
\text { Wage }\end{array}$ & $\begin{array}{c}\text { Spouse's } \\
\text { Wage }\end{array}$ & $\begin{array}{l}\text { Average } \\
\text { Lifetime } \\
\text { Earnings }\end{array}$ & $\begin{array}{c}\text { Social } \\
\text { Security } \\
\text { Retirement }\end{array}$ & \begin{tabular}{|c|} 
Social \\
Security \\
Disability
\end{tabular} & $\begin{array}{c}\text { Calendar } \\
\text { and Birth } \\
\text { Year }\end{array}$ & Education \\
\hline 1988 to 1992 & 54.6 & 54.6 & 54.6 & 54.6 & 54.6 & 54.6 & 54.6 & 54.6 & 54.6 & 54.6 & 54.5 & 54.6 & 55.6 & 53.3 \\
\hline 2001 to 2005 & 59.2 & 59.2 & 59.2 & 59.6 & 59.7 & 59.0 & 59.2 & 59.2 & 59.0 & 58.8 & 60.0 & 60.5 & 59.3 & 52.3 \\
\hline Increase & 4.7 & 4.7 & 4.7 & 5.0 & 5.2 & 4.4 & 4.7 & 4.7 & 4.4 & 4.2 & 5.6 & 5.9 & 3.8 & -1.0 \\
\hline Difference & & & 0.0 & -0.3 & -0.5 & 0.2 & 0.0 & 0.0 & 0.2 & 0.4 & -0.9 & -1.3 & 0.9 & 5.7 \\
\hline$\%$ of Increase & & & $0 \%$ & $-7 \%$ & $-10 \%$ & $5 \%$ & $0 \%$ & $0 \%$ & $5 \%$ & $9 \%$ & $-19 \%$ & $-27 \%$ & $19 \%$ & $122 \%$ \\
\hline
\end{tabular}

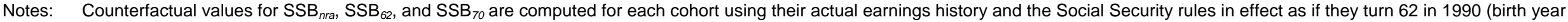

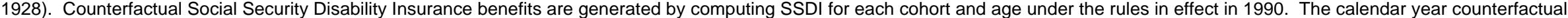
value is 1990; the birth year counterfactual value is 1928. For each other variable the counterfactual value is its average between 1988 and 1992.

The counterfactual LFPR is the predicted value (based on coefficient estimates from the specification with 2 year birth cohort effects) where the variable of interest is replaced by its counterfactual value, and all other values take on their actual values. 
Figure 1: LFPR Trends by Age Group (Source: Bureau of Labor Statistics)

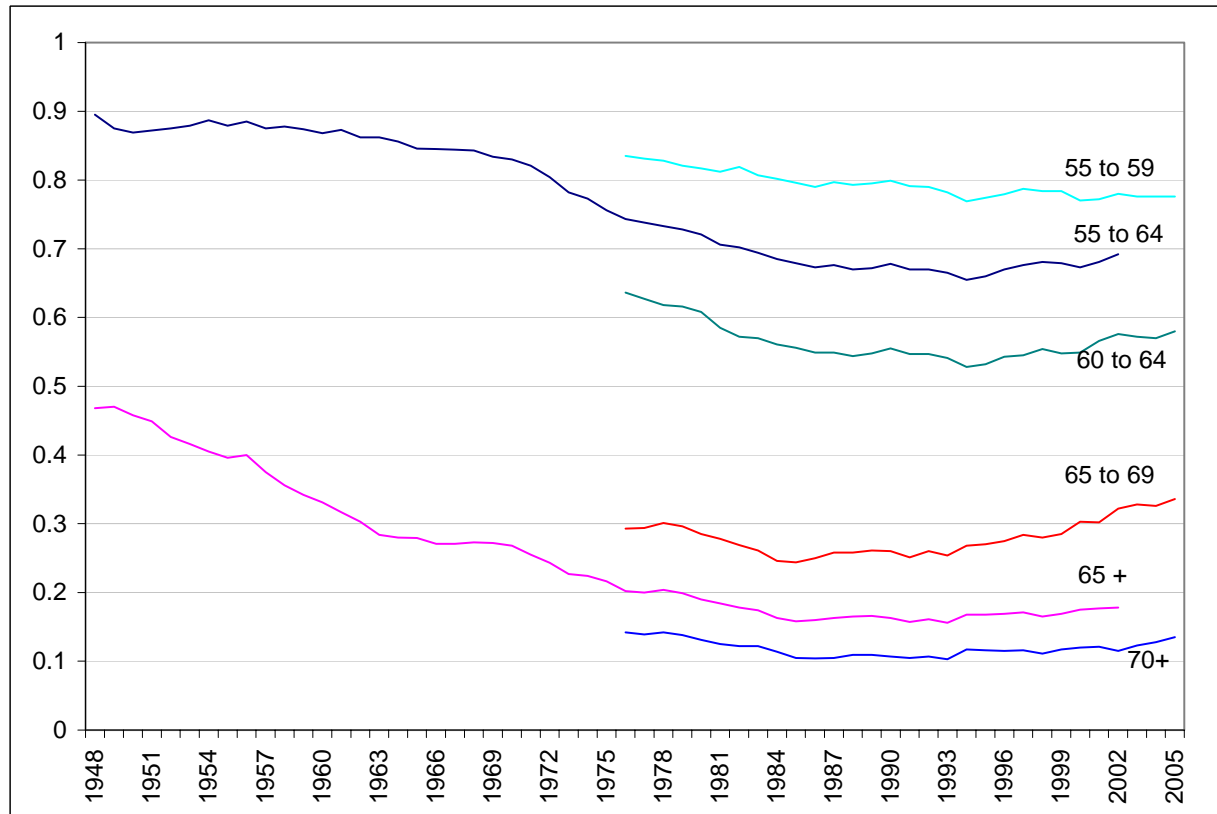

\section{Figure 3: LFPR By Age Group}

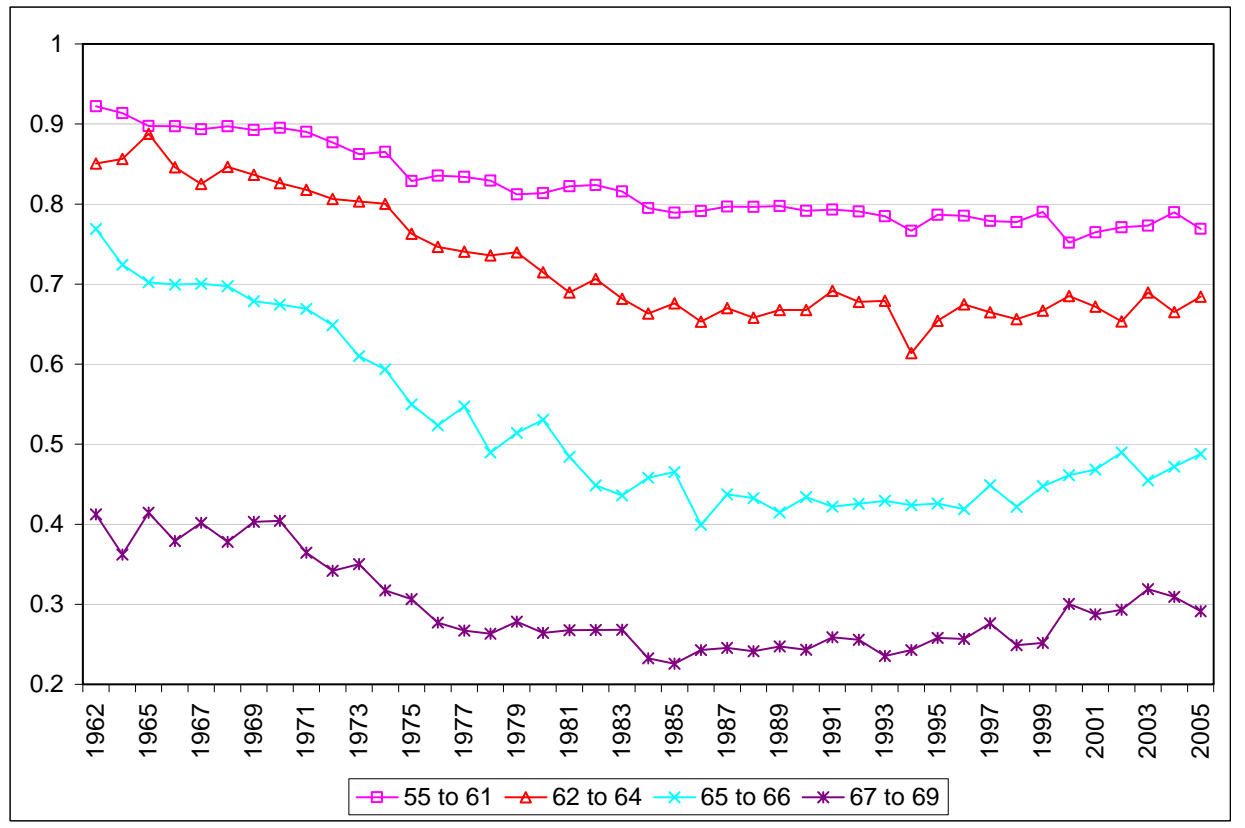

Figure 2: LFPR of Men Aged 55 to 69

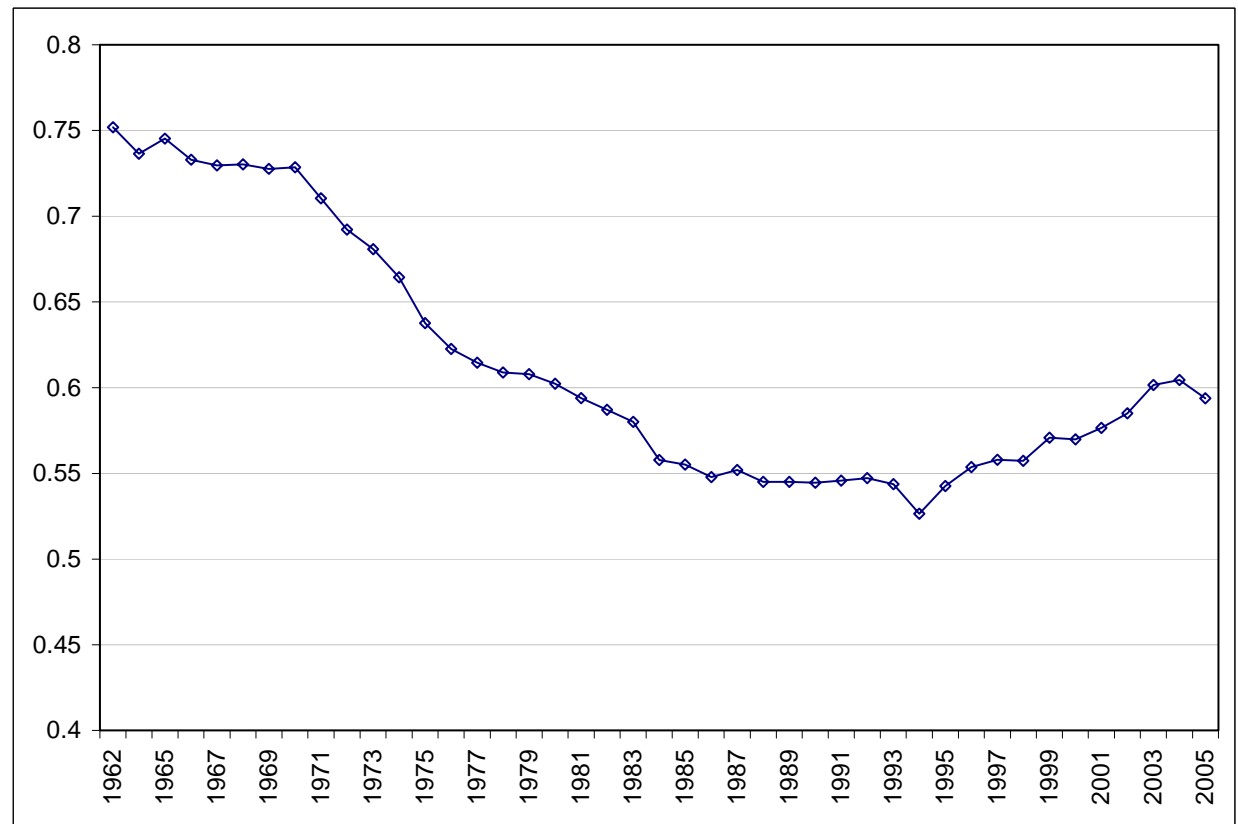

Figure 4: Educational Distribution

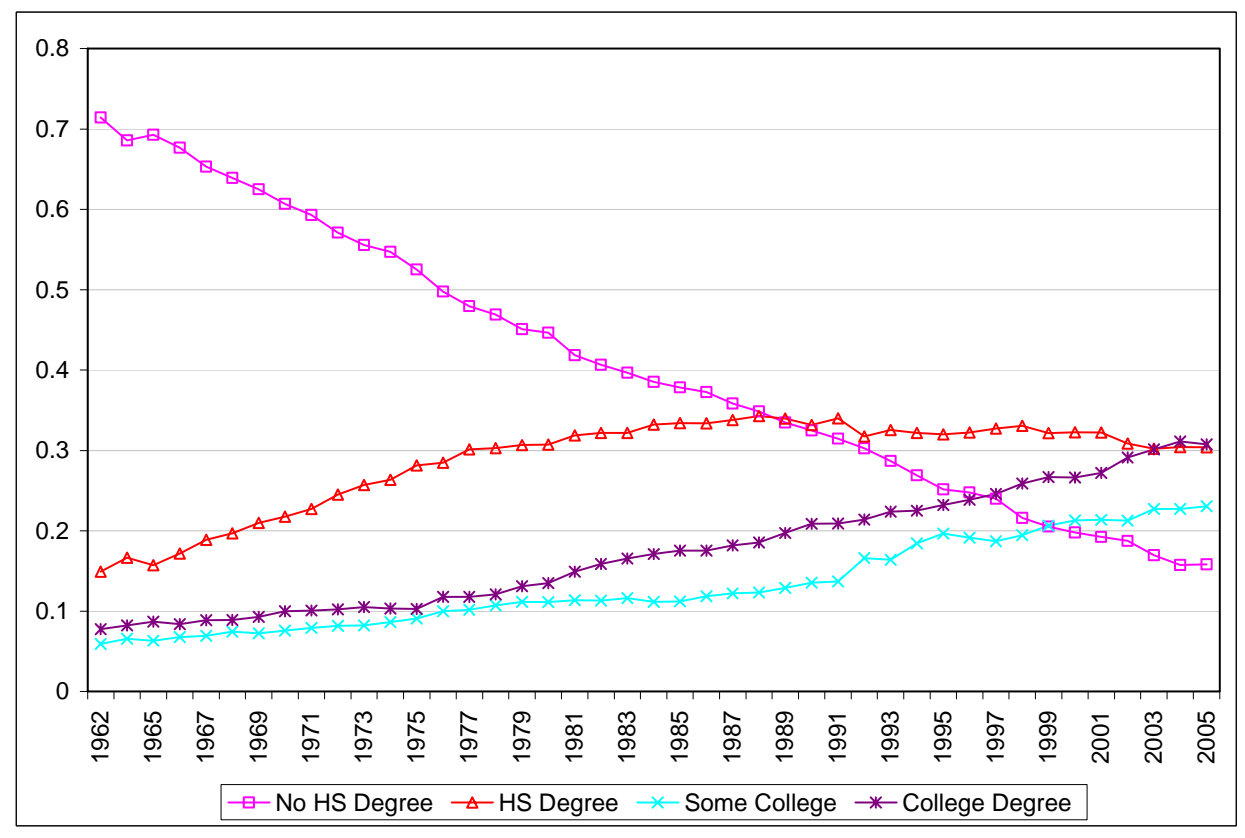




\section{Figure 5: LFPR by Education}

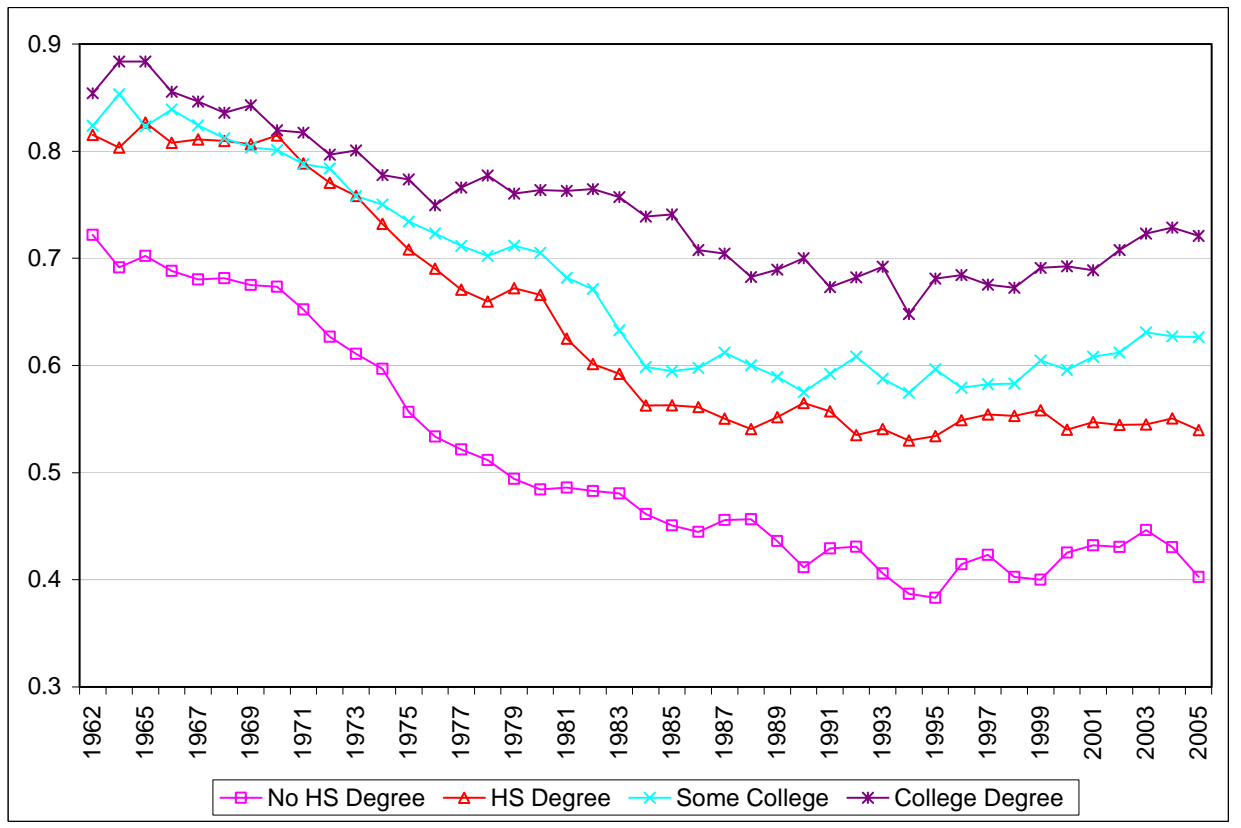

Figure 7: Monthly Social Security Benefit by Claim Age (2005 \$)

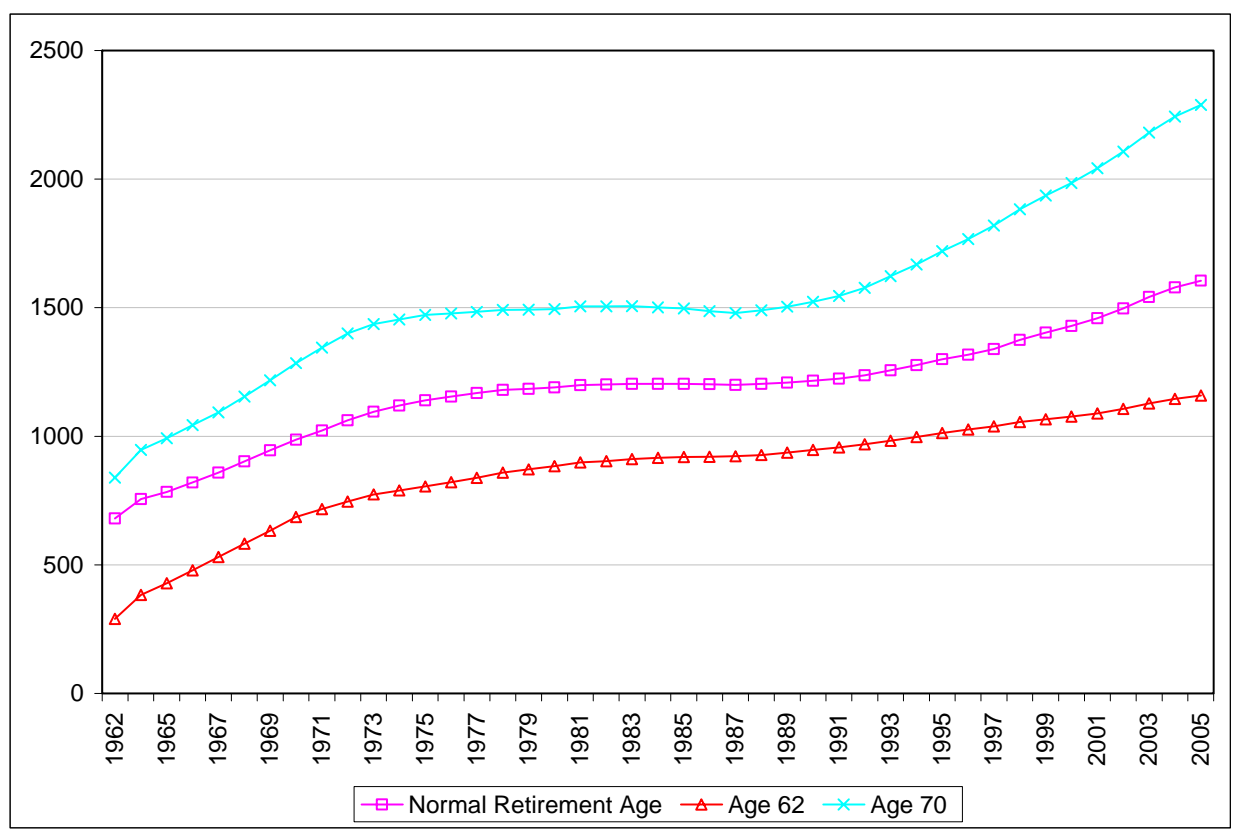

Figure 6: Incidence of Bad Health (by Data Source)

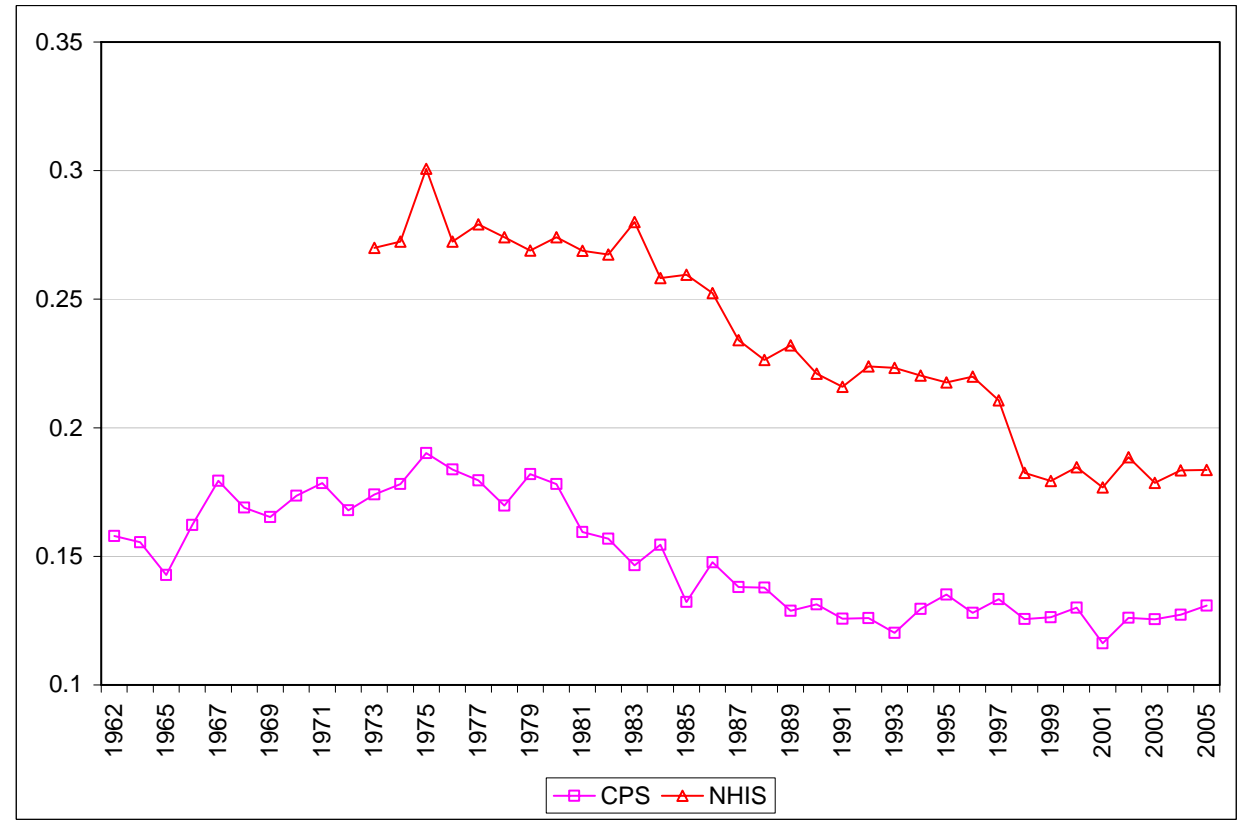

Figure 8: Monthly Social Security Disability Insurance Benefit (2005 \$)

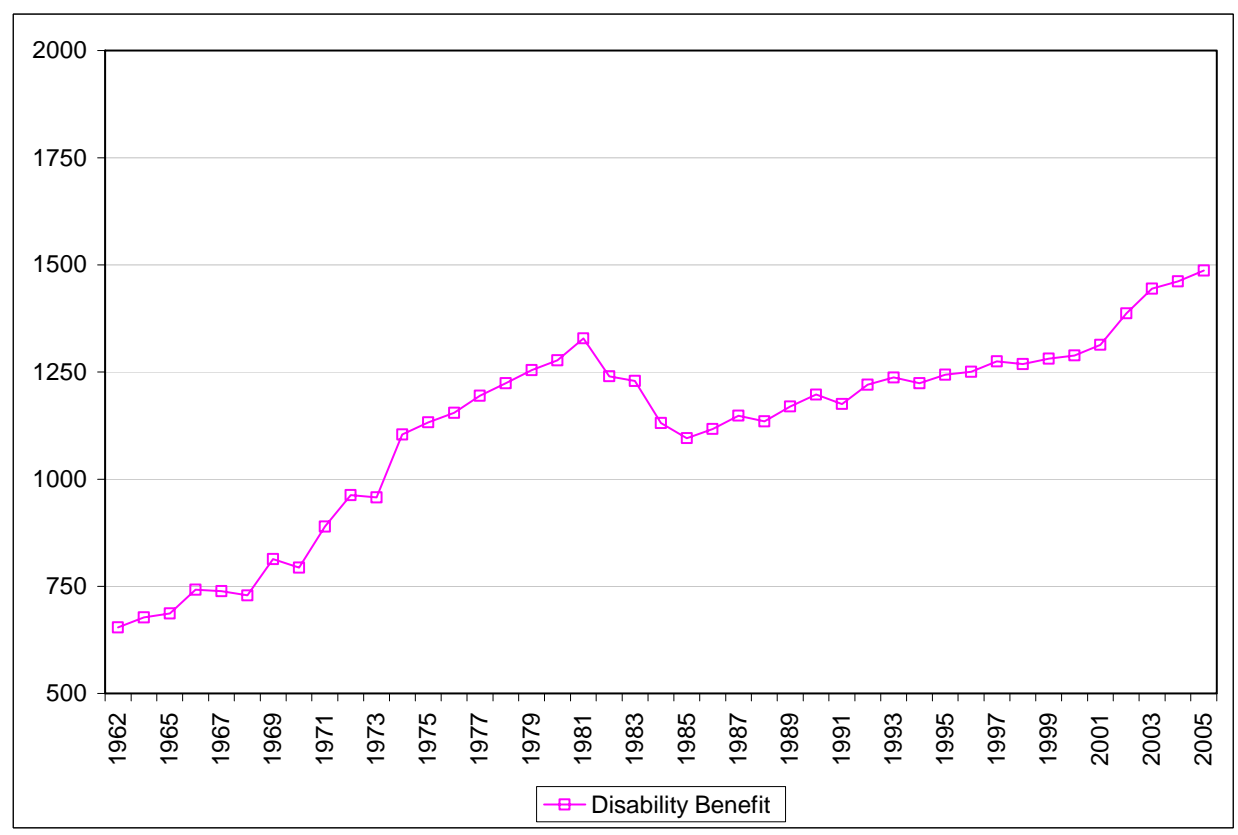


Figure 9: Average Monthly Earnings by Education (2005 \$)

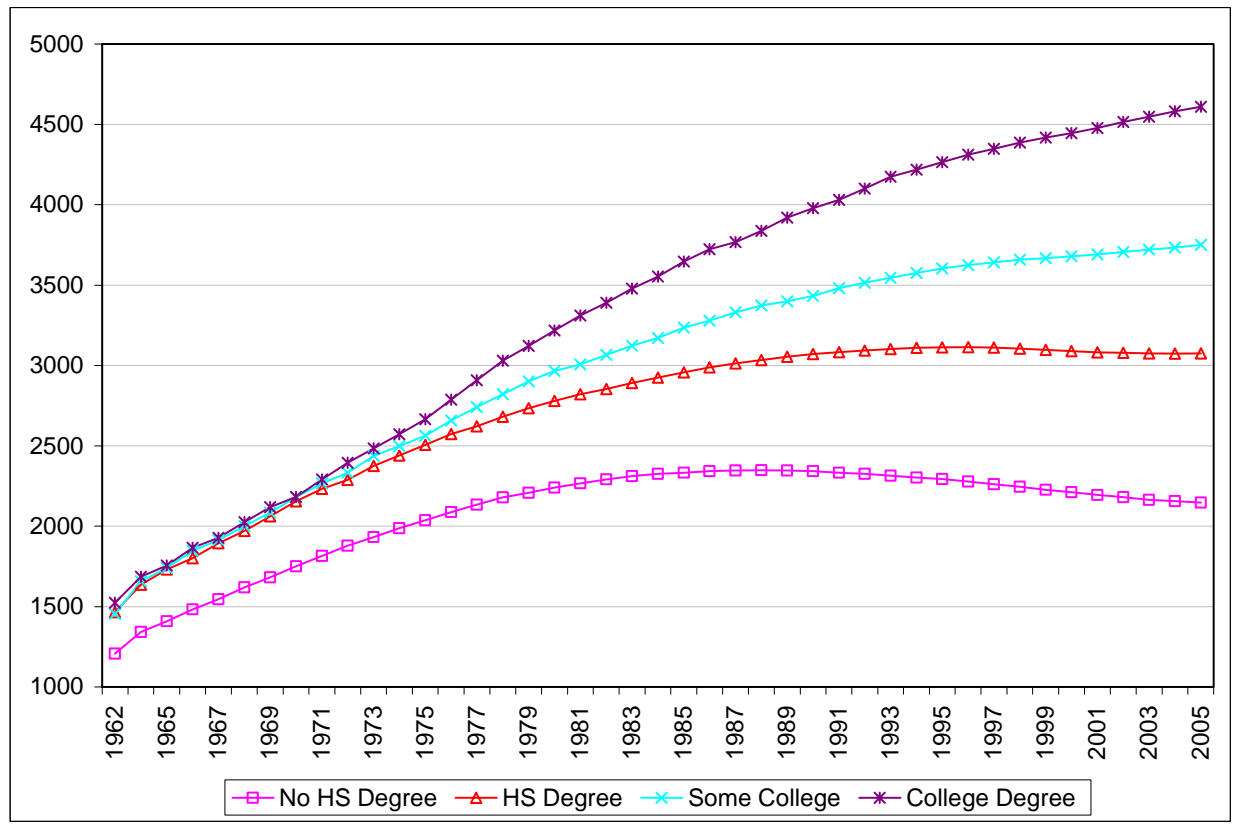

Figure 11: Spouse's Wage by Education of Husband (in logs, 2005 \$)

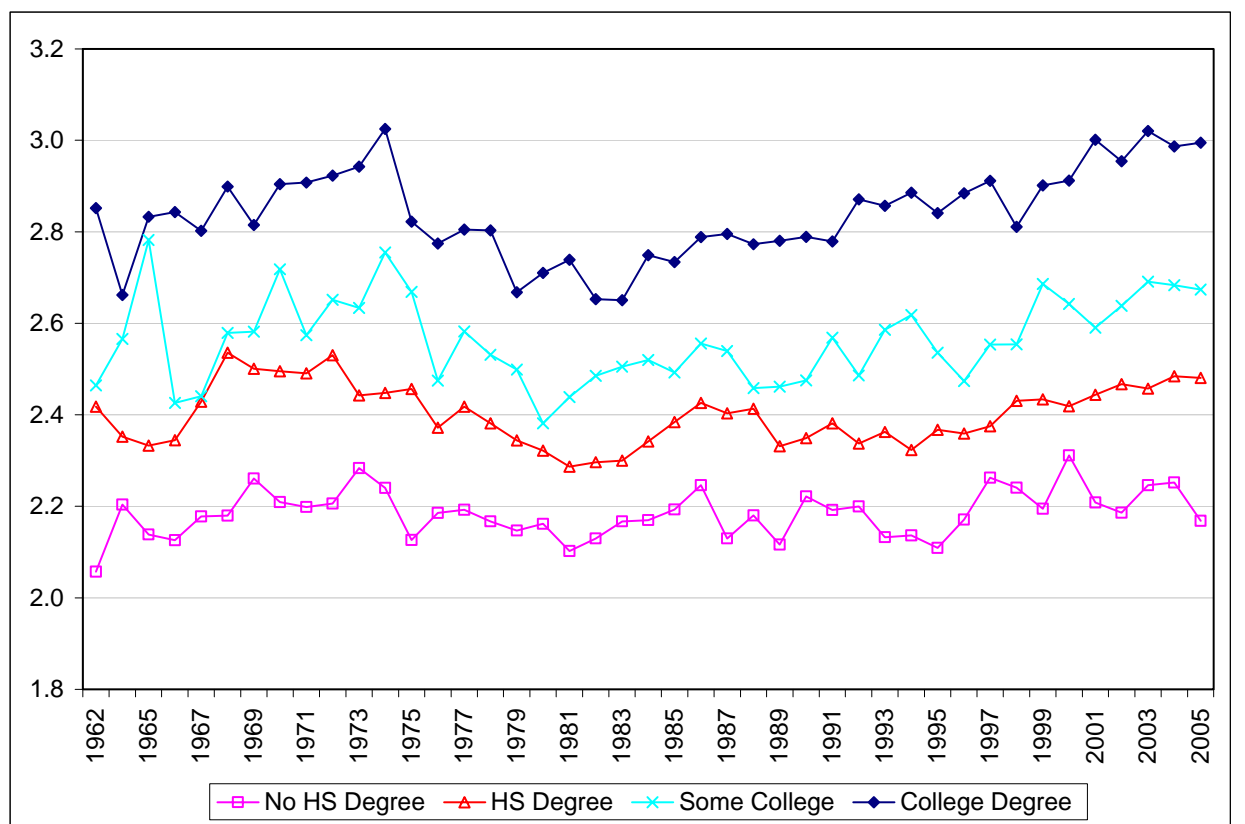

Figure 10: Male Wage by Education (in logs, 2005 \$)

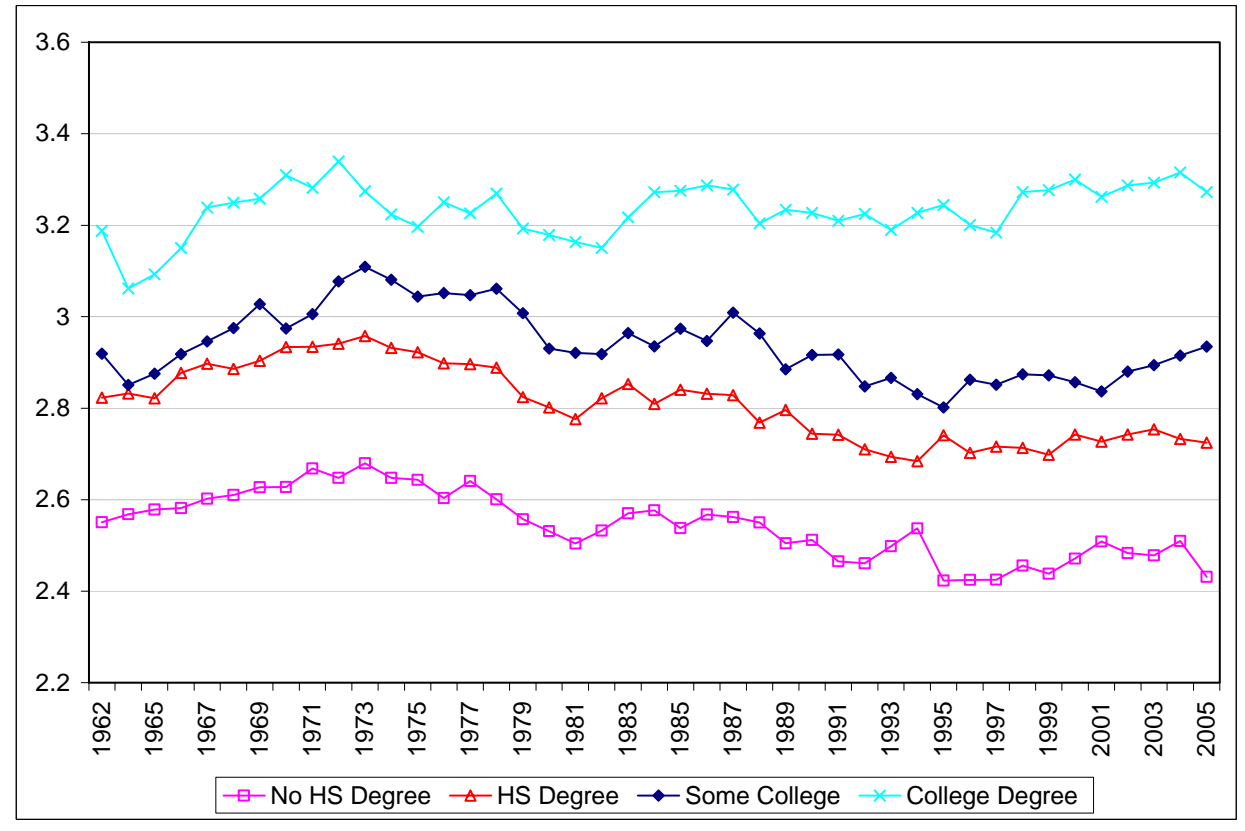

Figure 12: Pension and Retiree Health Insurance Coverage

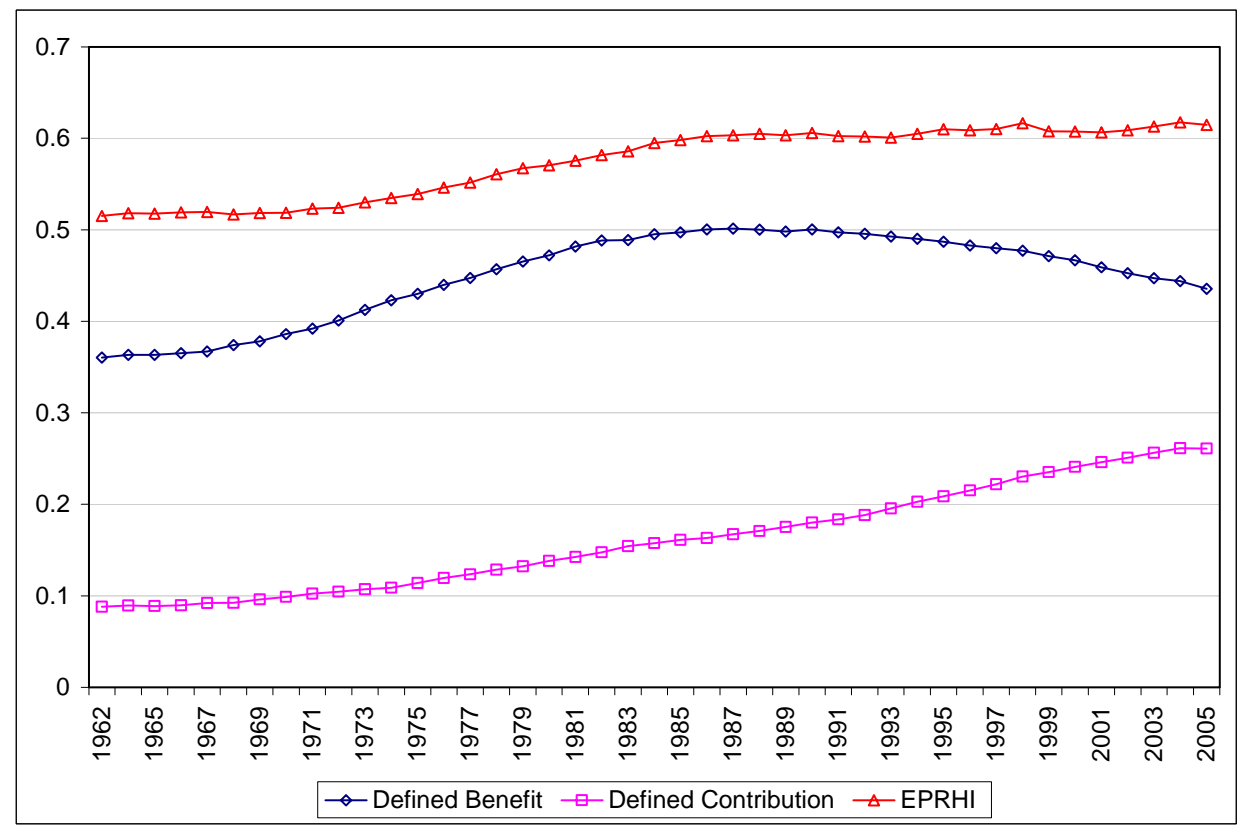


(a) Ages 55 to 69

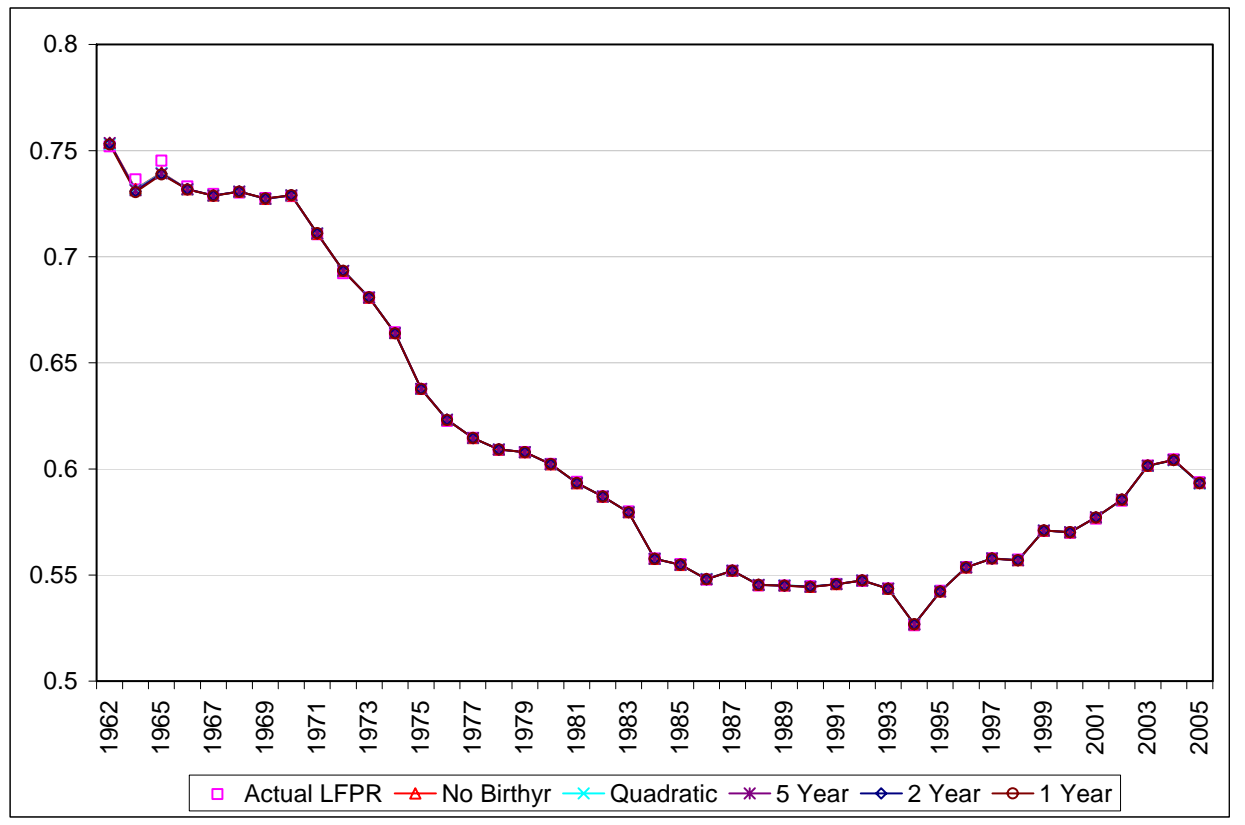

(c) Ages 62 to 64

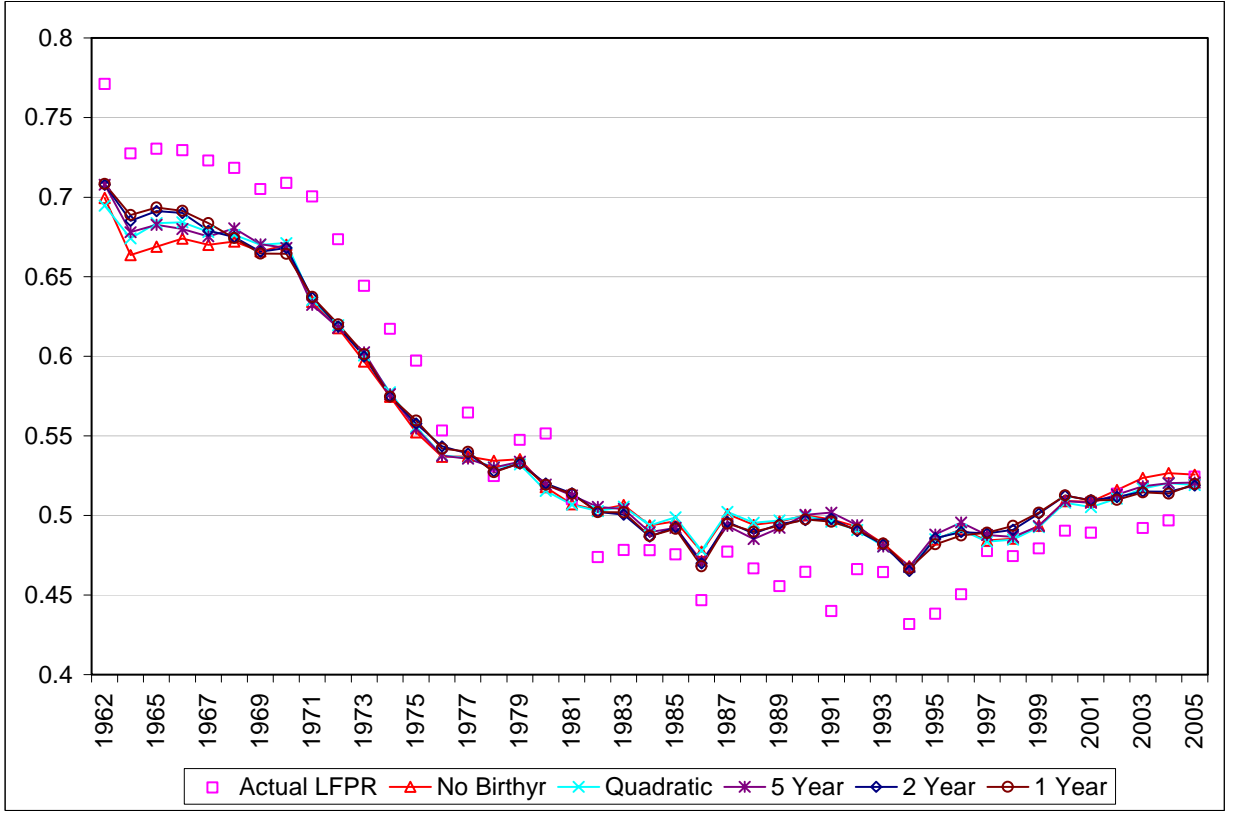

(b) Ages 55 to 61

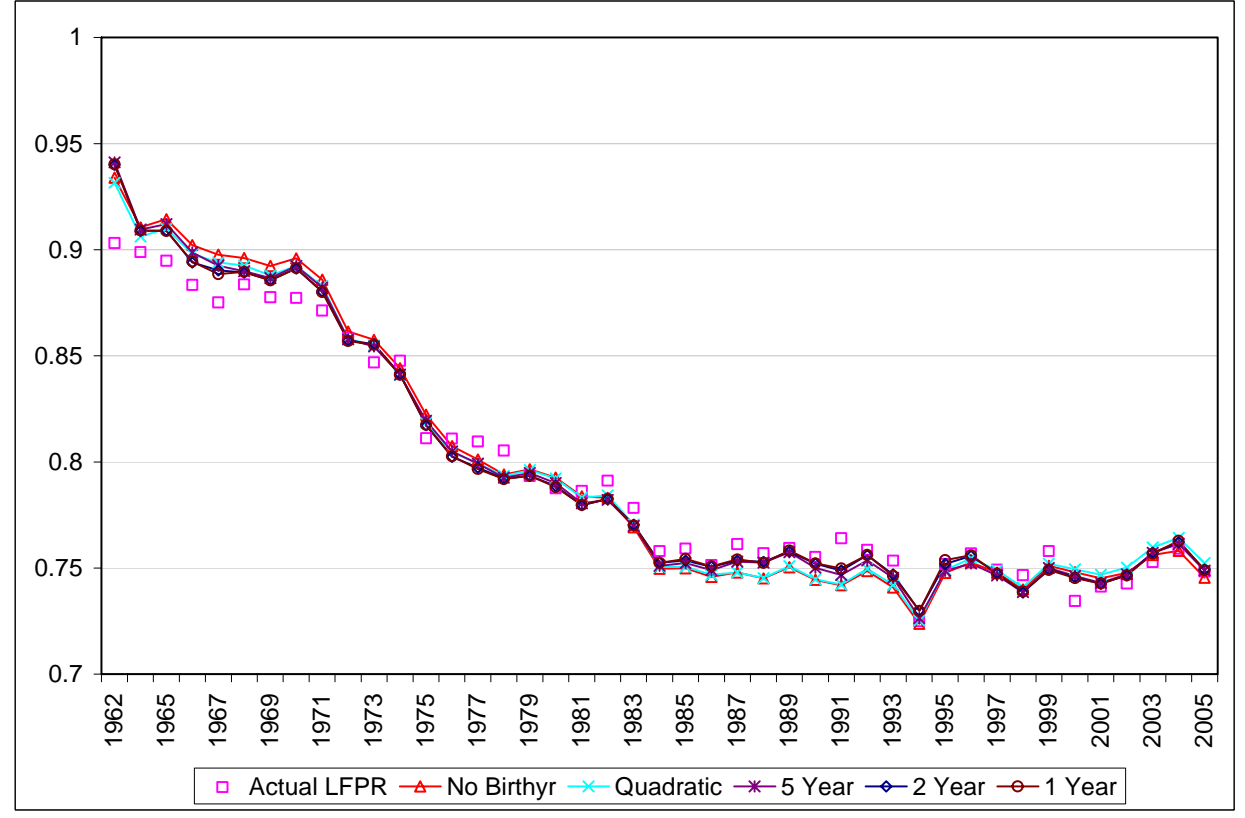

(d) Ages 65 to 66

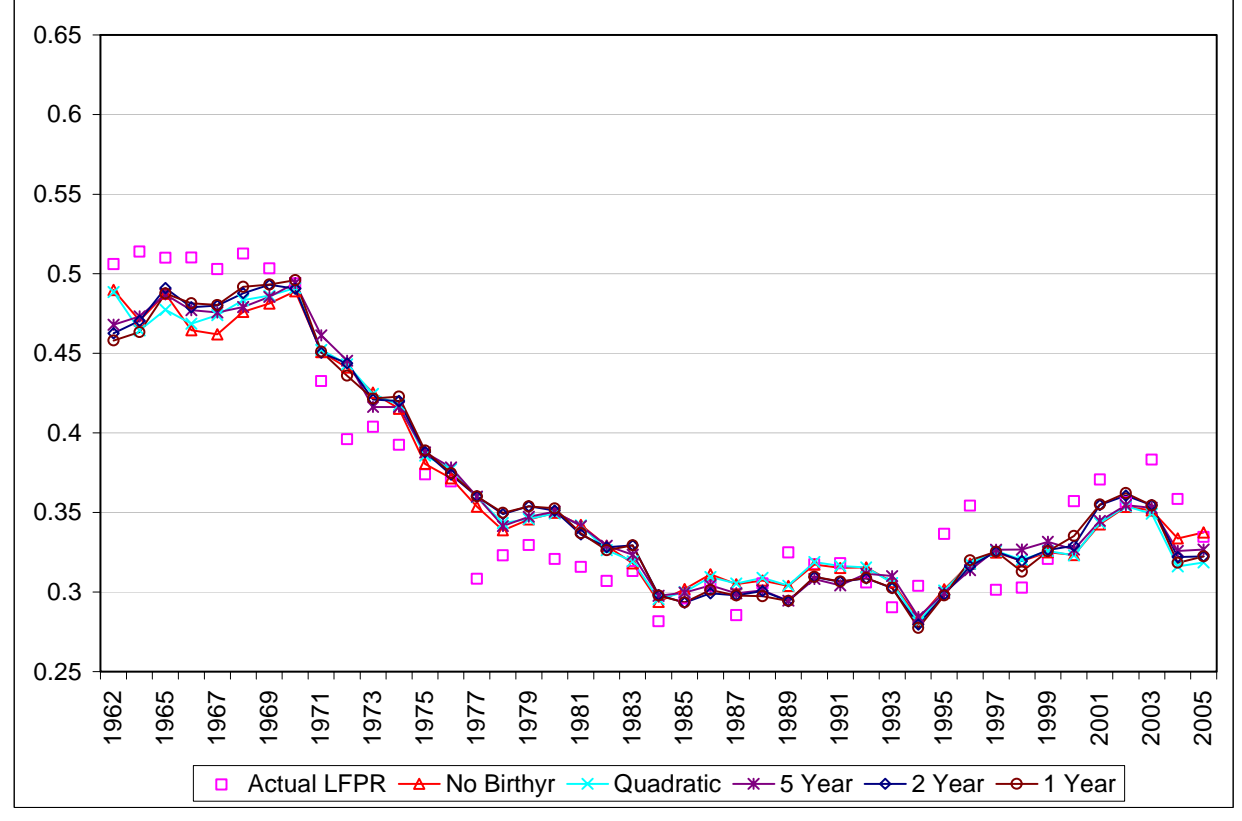


Figure 13(e): Ages 67 to 69

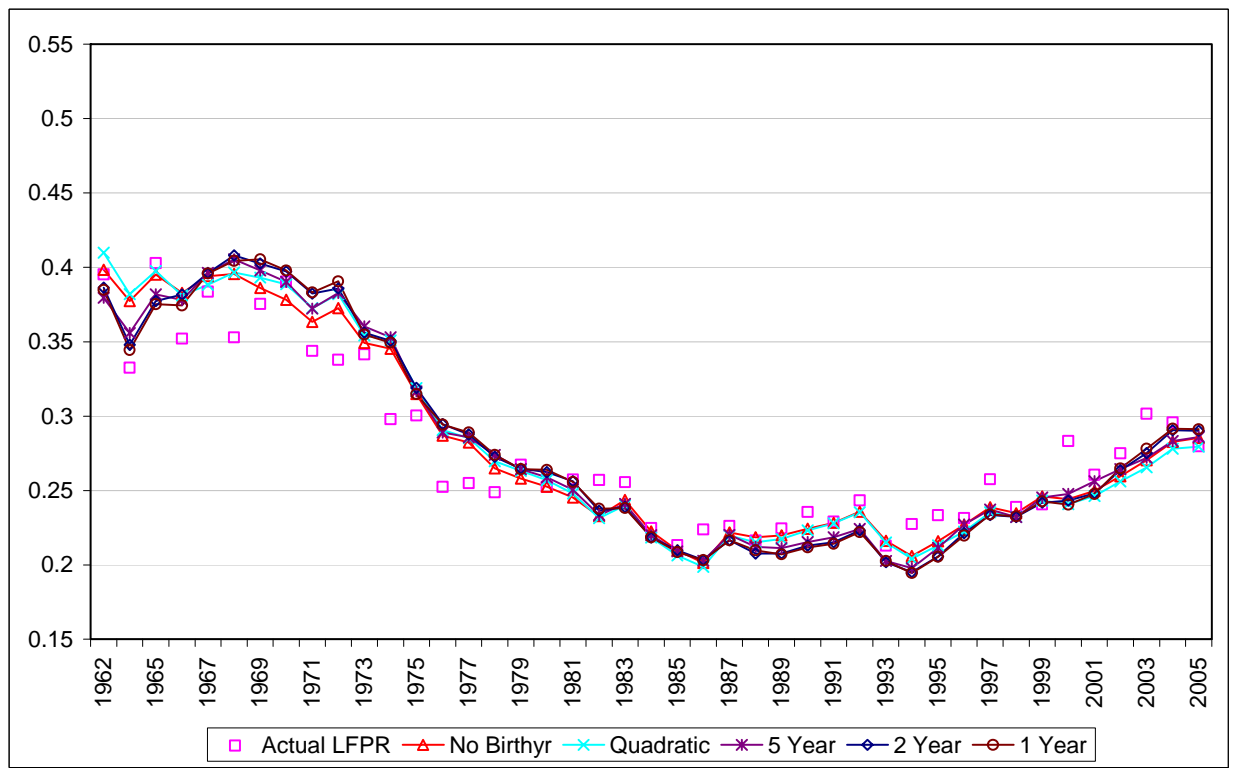

Figure 14: Downtrend Counterfactual: Social Security

(a) No Birth Cohort Effects

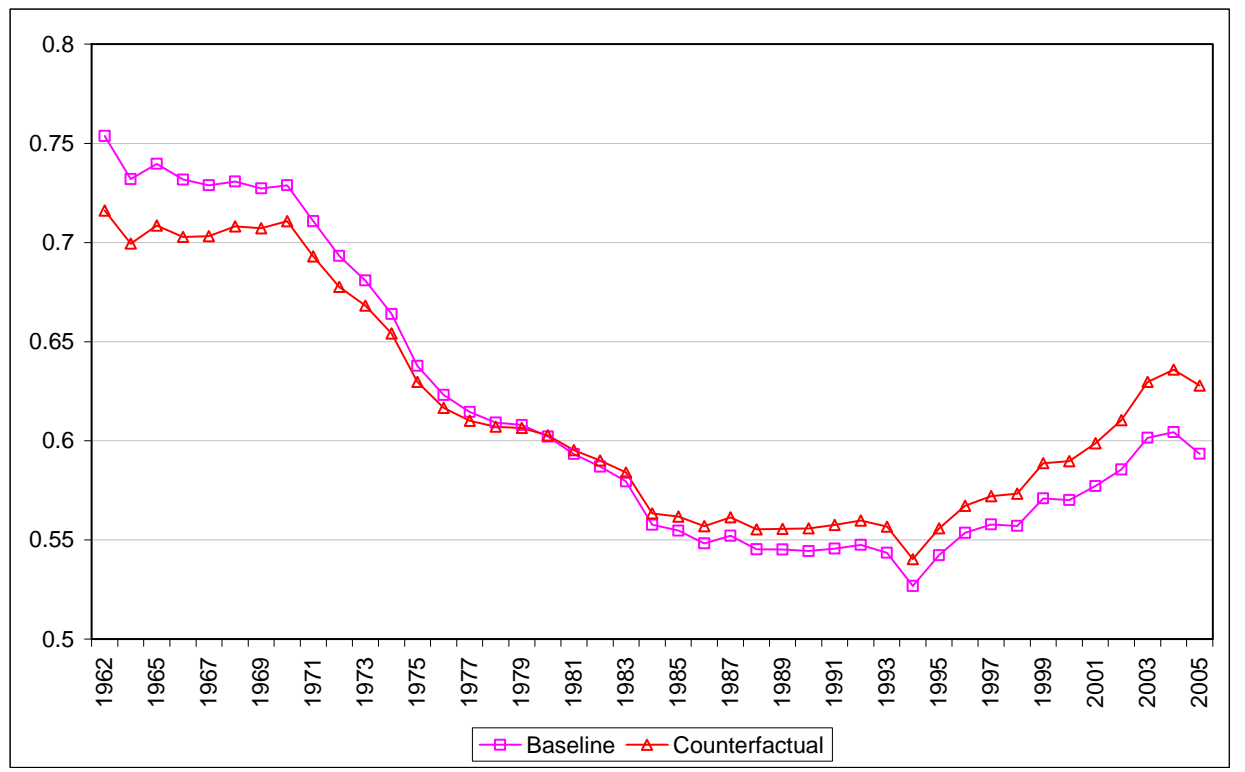

(b) 2 Year Birth Cohort Effects

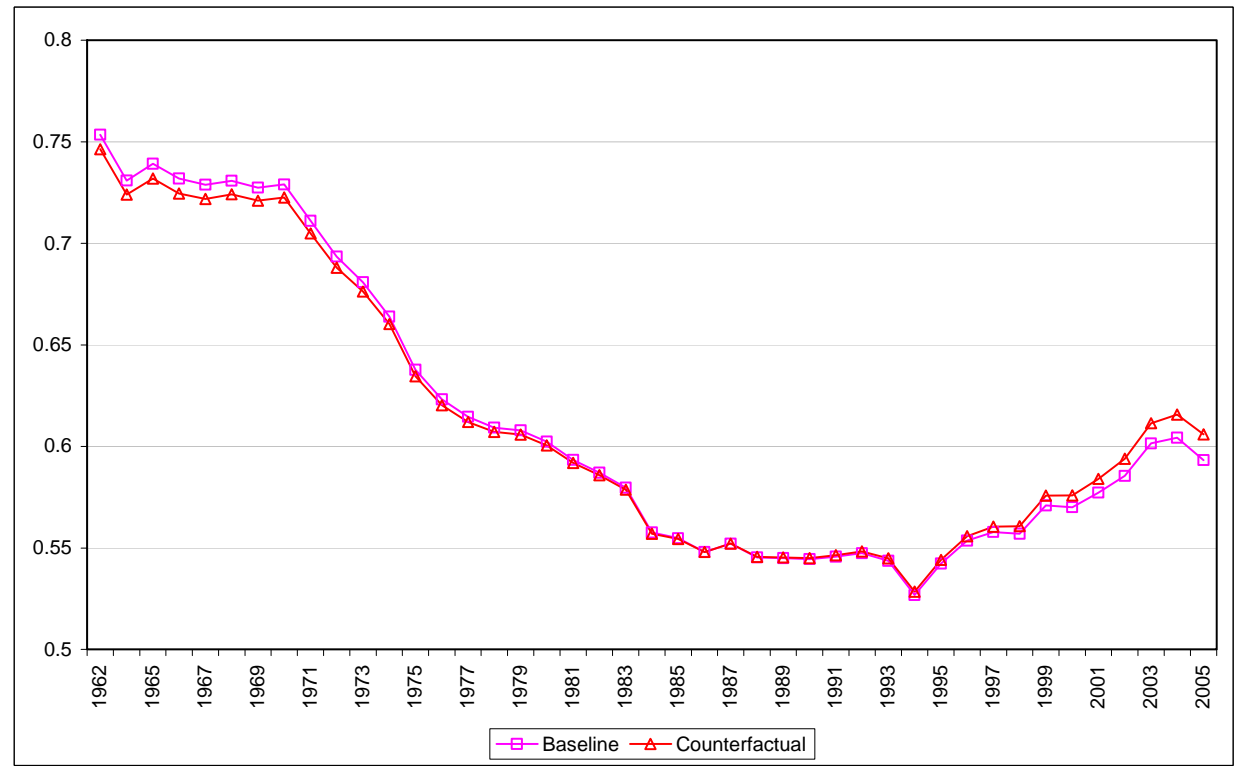




\section{Figure 15: Uptrend Counterfactual: Educational Distribution}

(a) No Birth Cohort Effects

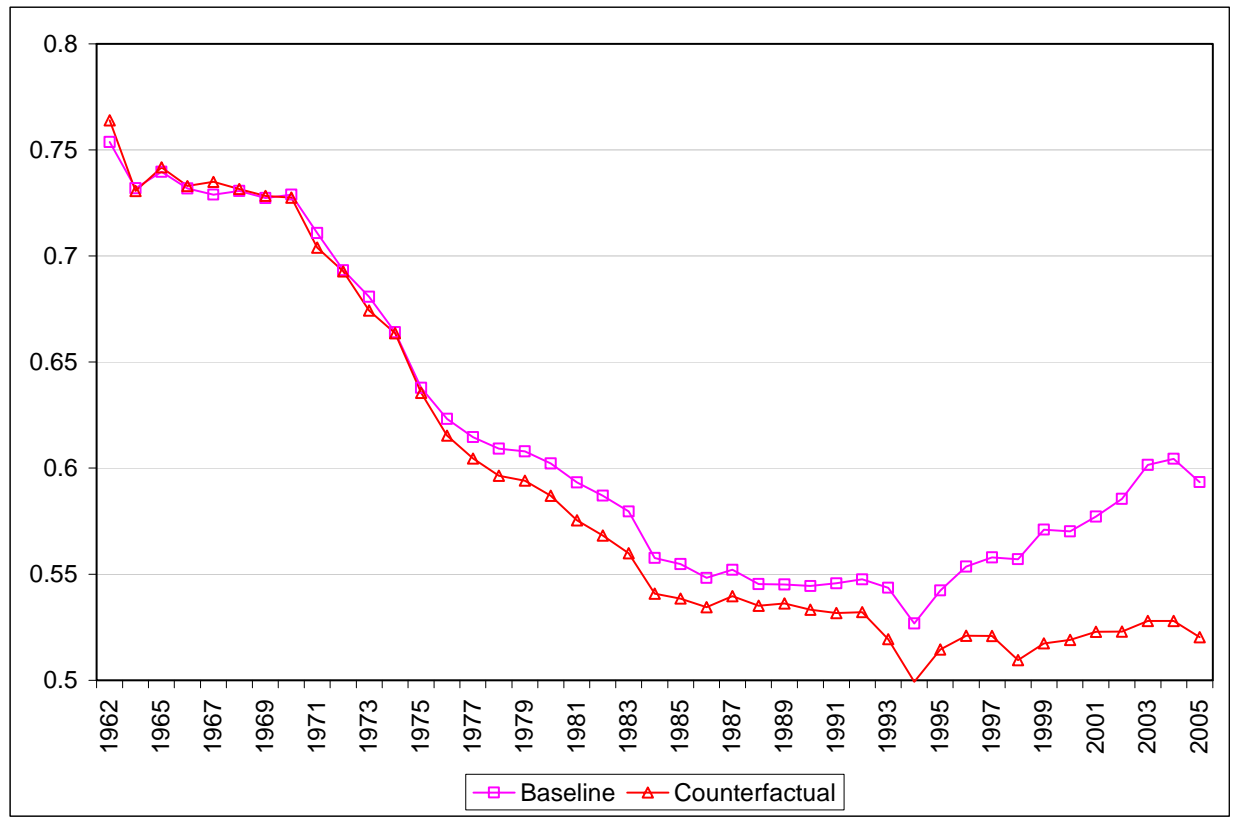

(b) 2 Year Birth Cohort Effects

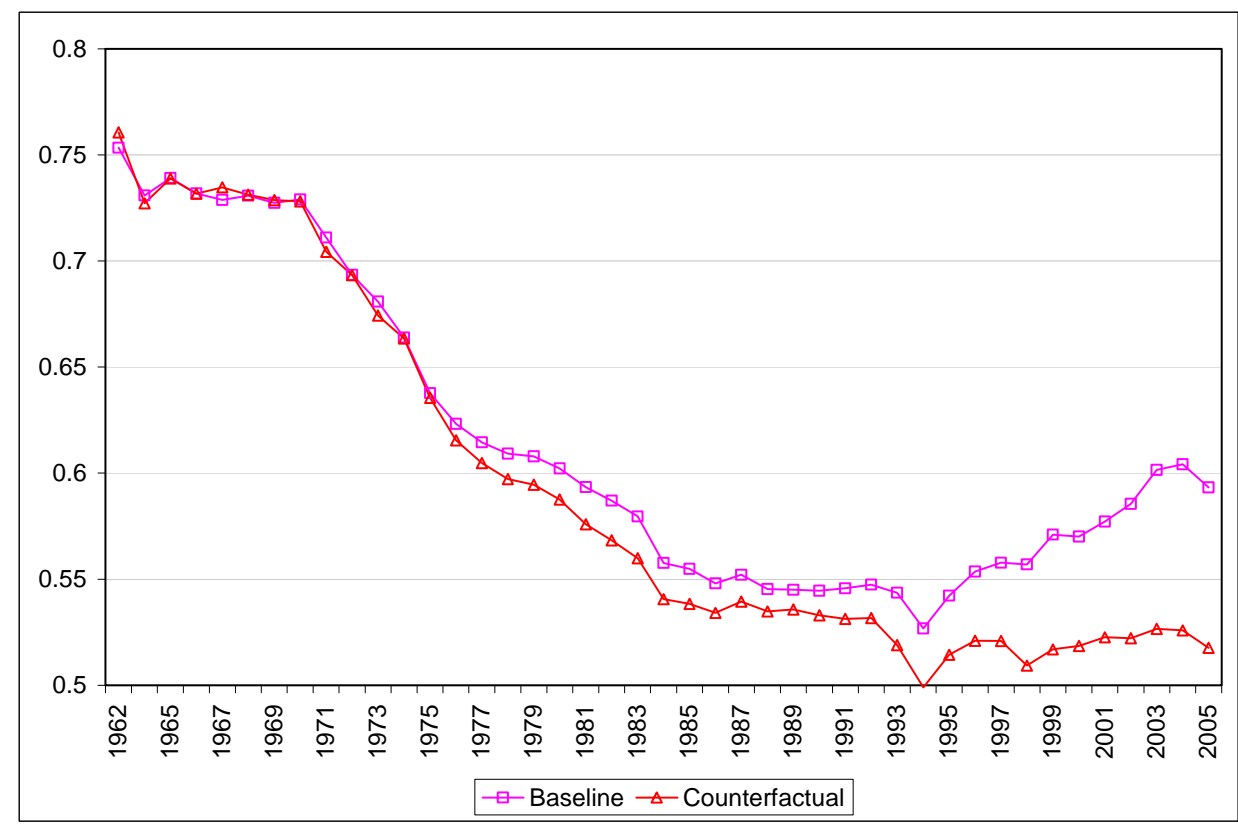

